\title{
Synthesis and RNA binding selectivity of oligonucleotides modified with five-atom TANA backbone structures
}

\author{
Khirud Gogoi, Anita D. Gunjal, Usha D. Phalgune and Vaijayanti A. Kumar* \\ Division of Organic Chemistry, National Chemical Laboratory, Dr. Homi Bhaba Road, \\ Pune, 411008, India.
}

E-mail: va.kumar@ncl.res.in

Table of Content

S 2-S 9 Experimental procedures and data of compounds in schemes 1, 2 and 3.

S 10-S $15{ }^{1} \mathrm{H}$ NMR of $3,12,13,14,15,16$ and $17,{ }^{13} \mathrm{C}$ NMR of $3,{ }^{31} \mathrm{P}$ of 14 and 17.

S 16-S 20 Mass of Compound 3, 4, 12, 13, 14, 15, 16 and 17

S 21 Conformational study data Table 1 for 18 and 19.

S 22-S $23{ }^{1} \mathrm{H}$ NMR of 18 and 19

S $24 \quad$ Experimental procedure of oligomers synthesis and their data Table 2.

S 25-S 30 MALDI-TOF mass of oligomers 20, 21, 22, 23, 24, 26, 27, 29, 30, 31 and 32

S 31-S 34 UV-melting data tables and UV-melting curves.

S $35 \quad$ CD spectra of modified and unmodified duplexes

S $36 \quad$ Mismatch UV-melting data tables and UV-melting curves.

S 37 Mismatch UV-melting data table 


\section{Experimental Procedure:}

Melting points of samples were determined in open capillary tubes using Buchi Melting point B-540 apparatus and are uncorrected. IR spectra were recorded on an infrared Fourier Transform spectrometer .Column chromatographic separations were performed using silica gel 60-120 and 230-400 mesh, Ethyl acetate, Petroleum ether, Dichloromethane and Methanol as the solvent system. ${ }^{1} \mathrm{H}$ and ${ }^{13} \mathrm{C}$ spectra were obtained using Bruker AC 200(200MHz), 400(400MHz) and 500(500MHz) NMR spectrometers. The optical rotation values were measured on Bellingham-Stanley Ltd, ADP220 polarimeter.

Synthesis of 5'-O-tosyl thymidine (2a): A solution of thymidine 1, 2.42g (10 mmol) in $30 \mathrm{ml}$ anhydrous pyridine was cooled to $0{ }^{\circ} \mathrm{C}$. Tosyl chloride $(2.3 \mathrm{~g}, 12 \mathrm{mmol})$ dissolved in $10 \mathrm{ml}$ of pyridine was then added drop wise during 4 hours. The reaction temperature was maintained at $0{ }^{\circ} \mathrm{C}$ during the addition. The reaction mixture was stirred for additional $4 \mathrm{~h}$ at room temperature. Pyridine was removed the under vacuum. The residue was dissolved in $100 \mathrm{ml}$ ethyl acetate and the organic layer was washed with $10 \%$ $\mathrm{NaHCO}_{3}$ solution followed by water. The tosyl thymidine $\mathbf{2 a}$ slowly crystallized out. The product was filtered and was dried under vacuum. Yield 3.2 $\mathrm{g}(80 \%)$.

M.p. 160-164 ${ }^{\circ} \mathrm{C} .{ }^{1} \mathrm{HNMR}:\left(\mathrm{CDCl}_{3}+1\right.$-drop DMSO-d6), (200MHz) $\delta 1.89(\mathrm{~s}, 3 \mathrm{H}), 2.1$ 2.25(m, 2H), 2.4(s, 3H), 3.98-4.1 (m, 3H), 4.24(m, 1H), 6.2(t, 1H), 7.33(d, 3H), 7.78(d, $2 \mathrm{H}), 10.14(\mathrm{~s}, 1 \mathrm{H})$.

Mass calculated 396.39 observed 396.46.

\section{Synthesis of 5'O-tosyl, 3'O-tert butyl dimethyl silyl thymidine (2b):}

A solution of 5' $O$ - tosyl thymidine $2 \mathbf{a}(3.1 \mathrm{~g}, 7.8 \mathrm{mmol})$, tert-butyl dimethyl silyl chloride (1.4g, $9.4 \mathrm{mmol})$, imidazole $(1.33 \mathrm{~g}, 19.6 \mathrm{mmol})$ in $10 \mathrm{ml}$ anhydrous DMF was stirred for 
$6 \mathrm{~h}$. DMF was removed the in vacuo and the residue was dissolved in $200 \mathrm{ml}$ ethyl acetate. The organic layer was washed with water $(3 \times 50 \mathrm{ml})$ followed by brine $(2 \times 30$ $\mathrm{ml}$ ). The organic layer was dried over anhydrous $\mathrm{Na}_{2} \mathrm{SO}_{4}$ and solvent was then removed in vacuo. The residue was redissolved in $20 \mathrm{ml}$ DCM and subjected to filtration column purification (50\% Pet Ether: Ethyl acetate). Pure compound 2b was obtained in 95\% yield, $3.8 \mathrm{~g}$.

${ }^{1} \mathrm{HNMR}:\left(\mathrm{CDCl}_{3}\right),(200 \mathrm{MHz}) \delta 0.06(\mathrm{~s}, 6 \mathrm{H}), 0.86(\mathrm{~s}, 9 \mathrm{H}) 1.89(\mathrm{~s}, 3 \mathrm{H}), 2.1(\mathrm{~m}, 1 \mathrm{H})$, 2.29(m,1H), 3.98-4.1 (m, 3H), 4.24(m,1H), 6.2(t, 1H), 7.33(d, 3H), 7.8(d, 2H), 9.7(s, $1 \mathrm{H})$.

Mass calculated 511.2 observed 511.87

\section{Synthesis of ethyl-[S- 5'-( 3'-O-TBDMS- Thymidinyl)-mercapto]-acetate 3:}

Solution of $\mathrm{NaH}(0.35 \mathrm{~g}, 60 \%$ solution in hexane, $8.7 \mathrm{mmol}$.) and ethyl mercapto acetate $(1 \mathrm{ml}, 8.7 \mathrm{mmol})$ in $5 \mathrm{ml}$ anhydrous DMF was stirred for 30 minutes. 5' $O$-tosyl, 3'O-tert butyl dimethyl silyl thymidine $2 \mathbf{b}(3.7 \mathrm{~g}, 7.23 \mathrm{mmol})$ dissolved in $5 \mathrm{ml}$ DMF was then added slowly. The reaction mixture was stirred for $1 \mathrm{~h}$ at RT. DMF was removed under reduced pressure, and the residue was dissolved in $200 \mathrm{ml}$ ethyl acetate. The organic layer was washed with water $(3 \times 50 \mathrm{ml})$ followed by washing with brine $(2 \times 30 \mathrm{ml})$. The organic layer was dried over anhydrous $\mathrm{Na}_{2} \mathrm{SO}_{4}$ and solvent removed in vacuo. The product was subjected to column chromatography purification (50\% Pet Ether: Ethyl acetate) to give pure $3,2.75 \mathrm{~g}, 80 \%$.

M.p. $122-124^{\circ} \mathrm{C}[\propto]_{25} \mathrm{D}=+19.4^{\circ}\left(\mathrm{c} 0.5, \mathrm{CHCl}_{3}\right)$.

${ }^{1} \mathrm{HNMR}:\left(\mathrm{CDCl}_{3}\right),(400 \mathrm{MHz}) \delta 0.05(\mathrm{~s}, 6 \mathrm{H}), 0.86(\mathrm{~s}, 9 \mathrm{H}) \quad 1.9(\mathrm{~s}, 3 \mathrm{H}), 2.09(\mathrm{~m}, 1 \mathrm{H})$, 2.26(m,1H), 2.9-3 $(\mathrm{m}, 2 \mathrm{H}), 3.22-3.31(\mathrm{q}, 2 \mathrm{H}), 4(\mathrm{q}, 1 \mathrm{H}), 4.16(\mathrm{q}, 2 \mathrm{H}), 4.26(\mathrm{~m}, 1 \mathrm{H}) 6.2(\mathrm{t}$, 1H), 7.33(d,1H), 9.4(b, 1H)

${ }^{13} \mathrm{C}$ NMR $\delta-4.8,-4.7,12.5,14.1,17.9,25.7,34.2,34.3,40.5,61.5,73.5,84.7,85.7$, 111.2, 135.4, 150.1, 163.7, 170.0.

Mass calculated 458.64 observed $497.4\left(+\mathrm{K}^{+}\right)$.

\section{Synthesis of $S$ - 5'-( 3'-O-TBDMS-thymidinyl)-mercapto-acetic acid 4:}


$5 \mathrm{ml} 2 \mathrm{M} \mathrm{NaOH}$ solution was added to the solution of $3(2.6 \mathrm{~g}, 5.47 \mathrm{mmol})$ in $10 \mathrm{ml}$ methanol. The reaction mixture was stirred for 30 minutes. The sodium salt of the acid and excess $\mathrm{NaOH}$ present in the solution was neutralized by DOWEX $50 \mathrm{H}^{+}$resin. The resin filtered and washed with 2:1 mixture of methanol:water. The filtrate was concentrated under vacuum and the dried by vacuum desiccation to give 5, $2.3 \mathrm{~g}$, (95\%)

M.p. $134-136^{\circ} \mathrm{C} . \quad{ }^{1} \mathrm{H}$ NMR $\left(\mathrm{D}_{2} \mathrm{O}\right) \quad \delta 0.06(\mathrm{~s}, 6 \mathrm{H}), 0.85(\mathrm{~s}, 9 \mathrm{H}), 1.66(\mathrm{~s}, 3 \mathrm{H}), 2.16(\mathrm{~m}, 2 \mathrm{H})$, 2.71-2.76(m, 2H), 3.22(q, 2H), 3.88(dd, 1H), 4.2(m, 1H), 5.99(t, 1H), 7.3(s, 1H).

Mass calculated 430.6 observed 453.11(+ $\left.\mathrm{Na}^{+}\right)$.

\section{Synthesis of 3'-deoxy-3'-azido- 5'-O-dimethoxytrityl- thymidine 6:}

A mixture of AZT 5 (2.68g, $10 \mathrm{mmol})$, dimethoxytrityl chloride (4g, $12 \mathrm{mmol})$, DMAP $(1 \mathrm{mmol})$, triethylamine $(7 \mathrm{ml}, 50 \mathrm{mmol})$ in $50 \mathrm{ml}$ anhydrous pyridine was stirred at RT for $6 \mathrm{~h}$. Pyridine was removed in vacuo and residue redissolved in $200 \mathrm{ml} \mathrm{DCM}$. The organic layer was washed with $10 \% \mathrm{NaHCO}_{3}$ solution $(2 \times 30 \mathrm{ml})$ followed by water $(2 \times 50$ $\mathrm{ml}$ ). The organic layer was dried over anhydrous $\mathrm{Na}_{2} \mathrm{SO}_{4}$ and concentrated to dryness. Column purification using $1 \%$ methanol-dichloromethane gave pure 6, $5.1 \mathrm{~g}, 90 \%$.

IR, v(cm $\left.{ }^{-1}\right)(\mathrm{CHCl} 3) ; 3128,3019,2110,1724,1670 \mathrm{~cm}^{-1} \quad{ }^{1} \mathrm{HNMR}:\left(\mathrm{CDCl}_{3}, 200 \mathrm{MHz}\right)$ $\delta \quad 1.51(\mathrm{~s}, 3 \mathrm{H}), 2.4-2.5(\mathrm{~m}, 2 \mathrm{H}), 3.3-3.5(\mathrm{~m}, 2 \mathrm{H}), 3.8(\mathrm{~s}, 6 \mathrm{H}), 4.0-(\mathrm{d}, 1 \mathrm{H}), 4.4(\mathrm{q}, 1 \mathrm{H})$, 6.25(t, 1H), 6.8-8.6(m,14H) Mass calculated 569.6 observed 568.3.

\section{Synthesis of 3'-deoxy-3'-amino 5'-O-dimethoxytrityl- thymidine 7:}

Compound 6 was dissolved $(1.5 \mathrm{~g}, 2.6 \mathrm{mmol})$ in $10 \mathrm{ml}$ methanol and to it was added $0.15 \mathrm{~g}(10 \%) \mathrm{Pd}-\mathrm{C}$ catalyst. Then mixture was subjected to catalytic hydrogenation at 40 Psi of hydrogen pressure for $3.5 \mathrm{~h}$. The catalyst was removed by filtration over celite and concentration of the filtrate in vacuo give $7,1.3 \mathrm{~g}, 90 \%$.

$\mathrm{IR}, \mathrm{v}\left(\mathrm{cm}^{-1}\right)(\mathrm{CHCl} 3) \quad 3398,3018,2924,2853,1701$, and 1686. ${ }^{1} \mathrm{HNMR}:\left(\mathrm{CDCl}_{3}\right.$, $200 \mathrm{MHz}) \delta 1.52(\mathrm{~s}, 3 \mathrm{H}), 2.17-2.3(\mathrm{~m}, 2 \mathrm{H}), 3.38(\mathrm{dd}, 1 \mathrm{H}), 3.48(\mathrm{dd}, 1 \mathrm{H}), 3.7-3.8(\mathrm{~m}, 2 \mathrm{H})$ 3.8(s,6H), $6.29(\mathrm{t}, 1 \mathrm{H}), 6.86(\mathrm{~d}, 4 \mathrm{H}), 7.2-7.5(\mathrm{~m}, 9 \mathrm{H}), 8.64(\mathrm{~s}, 1 \mathrm{H})$. Mass calculated 543.6 observed 543.7 . 
Synthesis of 3'-deoxy-3'-azido-5'-O-dimethoxytrityl-C ${ }^{4}$-(-1, 2, 4-triazol-1-yl)pyrimidine 2'-deoxyribonucleoside 8:

Triethylamine $(12.7 \mathrm{ml}, 91 \mathrm{mmol})$ was added drop wise to a stirred mixture of $1,2,4-$ triazole $(7 \mathrm{~g}, 100 \mathrm{mmol})$ and phosphoryl chloride $(2 \mathrm{ml}, 22 \mathrm{mmol})$ in $50 \mathrm{ml} \mathrm{CH}_{3} \mathrm{CN}$ at $0^{\circ} \mathrm{C}$. The solution of $6(3.5 \mathrm{~g}, 9.1 \mathrm{mmol})$ in $15 \mathrm{ml}$ dry $\mathrm{CH}_{3} \mathrm{CN}$ was then added dropwise. The reaction mixture was stirred at room temperature for $2.5 \mathrm{~h}$. Triethylamine $(4.4 \mathrm{ml})$ and water $(1.1 \mathrm{ml})$ were added at $0^{\circ} \mathrm{C}$ and the mixture was stirred for another 10 minutes. The solvent was evaporated and the residue was re-dissolved in $50 \mathrm{ml}$ ethyl acetate. The organic layer washed with water $(2 \times 50 \mathrm{ml})$ and saturated aqueous $\mathrm{NaCl}(2 \times 20 \mathrm{ml})$, dried over $\mathrm{Na}_{2} \mathrm{SO}_{4}$ and evaporated to dryness to give $3.6 \mathrm{~g}(92 \%) 8$ as yellow foam, which was used immediately for the next reaction.

\section{Synthesis of 2',3'-dideoxy-3'-azido-5'-dimethoxytrityl-5-methylcytidine 9:}

Concentrated aqueous ammonia $(10 \mathrm{ml})$ was added to the solution of $\mathbf{8}(3.5 \mathrm{~g}, 8 \mathrm{mmol})$ in $50 \mathrm{ml}$ dioxane. The reaction mixture was stirred at room temperature for 2.5 hours. The solvents were evaporated in vacuo and the residue redissolved in $\mathrm{CH}_{2} \mathrm{Cl}_{2}$ and purified by silica-gel column chromatography (eluted with $0-5 \%$ methanol in $\left.\mathrm{CH}_{2} \mathrm{Cl}_{2}\right)$ to afford $9(3 \mathrm{~g}$, 96\%) as white foam.

IR, $v\left(\mathrm{~cm}^{-1}\right)$ 3192, 2984, 2827, 2114, $1687.6 \quad{ }^{1} \mathrm{HNMR}:\left(\mathrm{CDCl}_{3}, 200 \mathrm{MHz}\right) \delta 1.52(\mathrm{~d}$, $3 \mathrm{H}), \quad 2.44(\mathrm{~m}, 1 \mathrm{H}), \quad 2.6(\mathrm{~m}, \quad 1 \mathrm{H}) \quad 3.33(\mathrm{dd}, \quad 1 \mathrm{H}), \quad 3.56(\mathrm{dd}, \quad 1 \mathrm{H}), \quad 3.8(\mathrm{~s}, \quad 6 \mathrm{H}) \quad 4.0$ $(\mathrm{m}, 1 \mathrm{H}), 4.3(\mathrm{~m}, 1 \mathrm{H}), 6.25(\mathrm{t}, 1 \mathrm{H}), 6.84(\mathrm{~d}, 4 \mathrm{H}), 7.3-7.5(\mathrm{~m}, 9 \mathrm{H}), 7.75(\mathrm{~s}, 1 \mathrm{H})$.

Mass Calculated 568.6 observed 568.4.

\section{5'-O-dimethoxy-trityl- $N^{4}$-benzoyl-2',3'-dideoxy-3'-azido -5- methylcytidine 10:}

Benzoyl chloride $(2.6 \mathrm{ml}, 22.7 \mathrm{mmol}$ ) was added drop wise slowly to a solution of $\mathbf{9}$ $(2.9 \mathrm{~g}, 7.56 \mathrm{mmol})$ in $40 \mathrm{ml}$ pyridine at $0^{\circ} \mathrm{C}$. The mixture was then stirred at room temperature overnight. Then $8 \mathrm{ml}$ water were added and the reaction mixture was stirred for $5 \mathrm{~min}$ at $0^{\circ} \mathrm{C}$, followed by addition of concentrated ammonia $(8 \mathrm{ml})$ at $0^{\circ} \mathrm{C}$ and stirring for another 30 minute. The solvent was evaporated in vacuo and the residue redissolved in $50 \mathrm{ml}$ ethyl acetate. Washed the organic layer with $10 \% \mathrm{NaHCO}_{3}$ solution $(3 \times 30 \mathrm{ml})$, water $(2 \times 50 \mathrm{ml})$ and saturated aqueous $\mathrm{NaCl}(2 \times 20 \mathrm{ml})$. The organic layer was then 
dried over $\mathrm{Na}_{2} \mathrm{SO}_{4}$ and evaporated to dryness. The residue was redissolved in $10 \mathrm{ml}$ DCM and purified by silica gel (60-120 mesh) column filtration (10\% ethyl acetate in petroleum ether) to afford $(2.9 \mathrm{~g}, 76 \%) \mathbf{1 0}$ as a white foam.

IR, $v\left(\mathrm{~cm}^{-1}\right)(\mathrm{CHCl} 3) 3189,3024,2110,1715,1705,1696,1685{ }^{1} \mathrm{HNMR}:\left(\mathrm{CDCl}_{3}\right.$, $200 \mathrm{MHz}) \quad \delta 1.7(\mathrm{~d}, 3 \mathrm{H}), 2.5(\mathrm{~m}, 2 \mathrm{H}), 3.36(\mathrm{dd}, 1 \mathrm{H}), 3.58(\mathrm{dd}, 1 \mathrm{H}), 3.8(\mathrm{~s}, 6 \mathrm{H}) 4.0$ $(\mathrm{m}, 1 \mathrm{H}), 4.3(\mathrm{~m}, 1 \mathrm{H}), 6.28(\mathrm{t}, 1 \mathrm{H}), 6.87(\mathrm{~m}, 4 \mathrm{H}), 7.3-8.3(\mathrm{~m}, 15 \mathrm{H})$. Mass calculated 673.33 observed 673.31, 695.27(+ $\left.\mathrm{Na}^{+}\right)$.

5'-O-dimethoxy-trityl- $N^{4}$-benzoyl-2',3'-dideoxy-3'-amino-5-methylcytidine 11: Compound $10(2.8 \mathrm{~g}, 4.1 \mathrm{mmol})$ was dissolved in $15 \%$ triethylamine in pyridine $(5 \mathrm{ml})$ and $\mathrm{H}_{2} \mathrm{~S}$ gas was bubbled into the solution at $0^{\circ} \mathrm{C}$ for 15 minutes. The solution was then stirred at room temperature for an additional 30 minutes and solvent removed in vacuo. The residue was purified by flash silica gel (200-400 mesh) column chromatography (2-5 $\%$ methanol in DCM) to afford 11, 2.2g (80\%).

IR, $v\left(\mathrm{~cm}^{-1}\right)(\mathrm{CHCl} 3)$ 3189, 3024, 2810, 1718, 1709, 1692, 1683.

${ }^{1} \mathrm{HNMR}:\left(\mathrm{CDCl}_{3}, 200 \mathrm{MHz}\right) \delta 1.71(\mathrm{~d}, 3 \mathrm{H}), 2.26(\mathrm{~m}, 1 \mathrm{H}), 2.4(\mathrm{~m}, 1 \mathrm{H}), 3.38(\mathrm{dd}, 1 \mathrm{H})$, 3.56(dd, $1 \mathrm{H}), 3.76(\mathrm{~m}, 2 \mathrm{H}), 3.8(\mathrm{~s}, 6 \mathrm{H}), 6.24(\mathrm{t}, 1 \mathrm{H}), 6.87(\mathrm{~m}, 4 \mathrm{H}), 7.32-8.3(\mathrm{~m}, 15 \mathrm{H})$. Mass calculated 647.33, observed 647.32, 669.29(+ $\left.\mathrm{Na}^{+}\right)$.

\section{Synthesis of 5'-O-DMT -tst-3'- $O$-TBDMS Dimer 12:}

To compound $4(1 \mathrm{~g}, 2.32 \mathrm{mmol})$ in dry acetonitrile (5 ml), HBTU (1g, $2.8 \mathrm{mmol})$, DIPEA (1.2 ml, $7 \mathrm{mmol})$ and $\mathrm{HOBt}(0.16 \mathrm{~g}, 1.2 \mathrm{mmol})$ were added and stirred for $15 \mathrm{~min}$. compound 7 (1.25g, $2.3 \mathrm{mmol})$ was dissolved in $3 \mathrm{ml}$ acetonitrile and was then added into the reaction mixture and further stirred at room temperature for $1 \mathrm{~h}$. The reaction mixture was concentrated to dryness, dissolved in ethyl acetate $(30 \mathrm{ml})$ and washed with $5 \% \mathrm{NaHCO}_{3}$ solution $(2 \times 10 \mathrm{ml})$. The organic layer was dried over anhydrous $\mathrm{Na}_{2} \mathrm{SO}_{4}$ and concentrated to get the crude product. This was purified by column chromatography using $\mathrm{CH}_{2} \mathrm{Cl}_{2} / \mathrm{MeOH}$ to get pure product $12,1.7 \mathrm{~g}, 78 \%$.

${ }^{1} \mathrm{HNMR}$ : $\left(\mathrm{CDCl}_{3}, 200 \mathrm{MHz}\right) \delta 0.07(\mathrm{~s}, 6 \mathrm{H}), 0.87(\mathrm{~s}, 9 \mathrm{H}), 1.82(\mathrm{~s}, 3 \mathrm{H}), 1.84(\mathrm{~s}, 3 \mathrm{H}), 2.3-2.4$ $(\mathrm{m}, 4 \mathrm{H}), 2.8-2.96(\mathrm{~m}, 2 \mathrm{H}), 3.3(\mathrm{q}, 2 \mathrm{H}), 3.66-3.82(\mathrm{~m}, 2 \mathrm{H}), 3.94(\mathrm{~m}, 1 \mathrm{H}), 3.99(\mathrm{~m}, 1 \mathrm{H})$, 
4.36(m, 1H), $4.41(\mathrm{~m}, 1 \mathrm{H}), 6.13-6.2(\mathrm{~m}, 2 \mathrm{H}), 6.8-6.84(\mathrm{~d}, 4 \mathrm{H})$, 7.17-7.69 (m, 11H), 8.63 (d, 2H).

Mass calculated 955.96 observed $979.0\left(+\mathrm{Na}^{+}\right), 994.23\left(+\mathrm{K}^{+}\right)$.

\section{Synthesis of 5'-O-DMT- cst-3'-O-TBDMS Dimer 15:}

To compound 4 (1g, $2.32 \mathrm{mmol})$ in dry acetonitrile (5ml), HBTU (1g, $2.8 \mathrm{mmol})$, DIPEA $(1.2 \mathrm{ml}, 7 \mathrm{mmol})$ and HOBt $(0.16 \mathrm{~g}, 1.2 \mathrm{mmol})$ were added and stirred for $15 \mathrm{~min} . \mathbf{1 1}(1.5$, $2.3 \mathrm{mmol}$.) dissolved in $4 \mathrm{ml}$ acetonitrile was then added into the reaction mixture and further stirred at room temperature for $1 \mathrm{~h}$. The reaction mixture was concentrated to dryness, dissolved in ethyl acetate $(30 \mathrm{ml})$ and washed with $5 \% \mathrm{NaHCO}_{3}$ solution $(2 \times 10$ $\mathrm{ml})$. The organic layer was dried over anhydrous. $\mathrm{Na}_{2} \mathrm{SO}_{4}$ and concentrated to get the crude product. This was purified by column chromatography using $\mathrm{CH}_{2} \mathrm{Cl}_{2} / \mathrm{MeOH}$ to get pure product $15,2 \mathrm{~g}, 80 \%$.

${ }^{1} \mathrm{HNMR}:\left(\mathrm{CDCl}_{3}, 200 \mathrm{MHz}\right) \delta 0.08(\mathrm{~s}, 6 \mathrm{H}), 0.88(\mathrm{~s}, 9 \mathrm{H}), 1.58(\mathrm{~s}, 3 \mathrm{H}), 1.9(\mathrm{~s}, 3 \mathrm{H}), 2.15-$ $2.34(\mathrm{~m}, 2 \mathrm{H}), 2.46-2.53(\mathrm{~m}, 2 \mathrm{H}), 2.85(\mathrm{~m}, 2 \mathrm{H}), 3.28(\mathrm{q}, 2 \mathrm{H}), 3.47(\mathrm{~m}, 2 \mathrm{H}), 3.96(\mathrm{~m}, 1 \mathrm{H})$, 4.1(d, 1H), $4.29(\mathrm{~m}, 1 \mathrm{H}), 4.76(\mathrm{~m}, 1 \mathrm{H}), 6.06(\mathrm{t}, 1 \mathrm{H}), 6.4(\mathrm{t}, 1 \mathrm{H}), 6.82-6.87(\mathrm{~d}, 4 \mathrm{H}), 7.24-$ $7.72(\mathrm{~m}, 15 \mathrm{H}), 7.82(\mathrm{~s}, 1 \mathrm{H}), 8.25(\mathrm{~s}, 1 \mathrm{H}), 8.29(\mathrm{~s}, 1 \mathrm{H})$.

Mass calculated 1059.18 observed 1059.47, $1081.44\left(+\mathrm{Na}^{+}\right)$.

\section{Synthesis of 5'-O-DMT tst-3'-OH Dimer 13:}

A solution of $12(1.6 \mathrm{~g}, 1.7 \mathrm{mmol})$ and TBAF $(0.65 \mathrm{~g}, 2.5 \mathrm{mmol})$ in $15 \mathrm{ml}$ anhydrous THF was stirred at RT for $1 \mathrm{~h}$. THF was evaporated in vacuo and residue re-dissolved in DCM $(50 \mathrm{ml})$. The solution was washed with water $(2 \times 20 \mathrm{ml})$ followed by brine. The organic layer was dried over anhydrous $\mathrm{Na}_{2} \mathrm{SO}_{4}$ and evaporated to dryness. Silica gel column chromatography gave the pure product $\mathbf{1 3}, 1.25 \mathrm{~g}, 90 \%$.

${ }^{1} \mathrm{H} \mathrm{NMR}\left(\mathrm{CDCl}_{3}, 400 \mathrm{MHz}\right) \delta 1.4$ (s, 3H), 1.9 (s, 3H), 2.27 (m, 1H), 2.4(m, 1H), 2.46(m, $2 \mathrm{H}), 2.92(\mathrm{~m}, 2 \mathrm{H}), 3.32(\mathrm{q}, 2 \mathrm{H}), 3.46(\mathrm{~m}, 2 \mathrm{H}), 3.79(\mathrm{~s}, 6 \mathrm{H}), 4.08-4.14(\mathrm{~m}, 2 \mathrm{H}), 4.38(\mathrm{~m}$, $1 \mathrm{H}), 4.75(\mathrm{~m}, 1 \mathrm{H}), 6.2(\mathrm{t}, 1 \mathrm{H}), 6.4(\mathrm{t}, 1 \mathrm{H}), 6.84(\mathrm{~d}, 4 \mathrm{H}), 7.2-7.8(\mathrm{~m}, 9 \mathrm{H}), 7.64(\mathrm{~s}, 1 \mathrm{H}), 8.0$ (b, NH).

Mass calculated 841.93 observed 841.4. 


\section{Synthesis of 5'-O-DMT-cst -3'-OH Dimer 16:}

A solution of $13(1.8 \mathrm{~g}, 1.67 \mathrm{mmol})$ and $\operatorname{TBAF}(0.67 \mathrm{~g}, 2.54 \mathrm{mmol})$ in $15 \mathrm{ml}$ anhydrous THF was stirred at RT for $1 \mathrm{~h}$. The THF was evaporated in vacuo and residue was redissolved in DCM $(50 \mathrm{ml})$. The solution was washed with water $(2 \times 20 \mathrm{ml})$ followed by brine. The organic layer was dried over anhydrous $\mathrm{Na}_{2} \mathrm{SO}_{4}$ and evaporated to dryness. Silica gel column chromatography gave the pure product 15, 1.48g, $92 \%$.

${ }^{1} \mathrm{H} \mathrm{NMR}\left(\mathrm{CDCl}_{3}, 400 \mathrm{MHz}\right) \delta 1.6(\mathrm{~s}, 3 \mathrm{H}), 1.9$ (s, 3H), 2.35 ( t, 2H), $2.5(\mathrm{~m}, 2 \mathrm{H}), 2.8-2.9$ (m, 4H), $3.5(\mathrm{~m}, 2 \mathrm{H}), 3.8(\mathrm{~s}, 6 \mathrm{H}), 4.02(\mathrm{~m}, 1 \mathrm{H}), 4.1(\mathrm{~m}, 1 \mathrm{H}), 4.4(\mathrm{~m}, 1 \mathrm{H}), 4.73(\mathrm{~m}, 1 \mathrm{H})$, $6.1(\mathrm{t}, 1 \mathrm{H}), 6.4(\mathrm{t}, 1 \mathrm{H}), 6.85(\mathrm{~d}, 4 \mathrm{H}), 6.8(\mathrm{~d}, 4 \mathrm{H}), 7.2-7.53(\mathrm{~m}, 13 \mathrm{H}), 7.8(\mathrm{~s}, 1 \mathrm{H}), 8.25(\mathrm{~d}$, $2 \mathrm{H})$.

Mass calculated 945.05 observed $968.2\left(+\mathrm{Na}^{+}\right)$.

\section{5'-O-(4, 4'-dimethoxy) trityl -tst- 3'-O-(2-cyanoethyl-N, N-} diisopropylphosphoramidite)-dimer 14:

Compound $13(0.9 \mathrm{~g}, 1.07 \mathrm{mmol})$ was dissolved in dry DCM $(10 \mathrm{ml})$ followed by the addition of tetrazole $(0.12 \mathrm{~g}, 1.7 \mathrm{mmol})$ and 2-cyanoethyl-N,N,N',N'-tetraisopropylphosphorodiamidite $(0.55 \mathrm{ml}, 1.7 \mathrm{mmol})$ and the reaction mixture was stirred at room temperature for $12 \mathrm{~h}$. The contents were then diluted with dry DCM and washed with 5\% $\mathrm{NaHCO}_{3}$ solution. The organic phase was dried over anhydrous. $\mathrm{Na}_{2} \mathrm{SO}_{4}$ and concentrated to a foam. The residue was dissolved in DCM and precipitated with hexane to obtain $14(0.73 \mathrm{~g}, 65 \%)$. The phosphoramidite 14 was dried overnight over $\mathrm{P}_{2} \mathrm{O}_{5}$ and $\mathrm{KOH}$ in a desiccator before applying on DNA synthesizer. TLC shows two close moving spots for two diasteromers $\left(\mathrm{R}_{\mathrm{f}}=0.5,2 \%\right.$ methanol-dichlromethane $)$

${ }^{31} \mathrm{P}$ NMR $\left(\mathrm{CDCl}_{3}\right) \delta 149.0,149.08 .{ }^{1} \mathrm{H}$ NMR $\left(\mathrm{CDCl}_{3}, 400 \mathrm{MHz}\right) \delta 1.2(\mathrm{~d}, 12 \mathrm{H}), 1.41(\mathrm{~s}$, $3 \mathrm{H}), 1.92(\mathrm{~s}, 3 \mathrm{H}), 2.47(\mathrm{~m}, 4 \mathrm{H}), 2.47(\mathrm{~s}, 2 \mathrm{H}), 2.78(\mathrm{~m}, 2 \mathrm{H}), 2.96(\mathrm{~m}, 2 \mathrm{H}), 3.29(\mathrm{~m}, 2 \mathrm{H}), 3.5-$ 3.61(m, 6H), 3.73( m, 1H), 3.8(s, 6H), 3.85( m, 1H), 4.13-4.24( m, 4H), 4.5(m, 1H), 4.7(m, 1H), 6.1(t, 1H), 6.4(t,1H), 8.85(d, 4H), 7.2-7.4(m, 10H), 7.6(s, 1H).

Mass calculated 1042.1 observed 1041.5.

\section{5'-O-(4, 4'-dimethoxy) trityl-cst-3'-O-(2-cyanoethyl-N, N- diisopropylphosphoramidite) dimer 17:}


Compound 16 (1g, $1.05 \mathrm{mmol})$ was dissolved in dry DCM (10 ml) followed by the addition of tetrazole $(0.12 \mathrm{~g}, 1.7 \mathrm{mmol})$ and 2-cyanoethyl-N,N,N',N'-tetraisopropylphosphorodiamidite $(0.54 \mathrm{ml}, 1.7 \mathrm{mmol})$ and the reaction mixture was stirred at room temperature for $16 \mathrm{~h}$. The contents were then diluted with dry dichloromethane and washed with $5 \% \mathrm{NaHCO}_{3}$ solution. The organic phase was dried over anhydrous. $\mathrm{Na}_{2} \mathrm{SO}_{4}$ and concentrated to a foam. The residue was dissolved in DCM and precipitated with hexane to obtain $17(0.72 \mathrm{~g}, 60 \%)$. The phosphoramidite 17 was dried overnight over $\mathrm{P}_{2} \mathrm{O}_{5}$ and $\mathrm{KOH}$ in a desiccator before using on DNA synthesizer. TLC shows two close moving spots for two diastreomers ( $\mathrm{Rf}=0.6,2 \%$ methanol-dichlromethane)

${ }^{31} \mathrm{P}$ NMR $\left(\mathrm{CDCl}_{3}\right) \quad \delta 148.91,147.03 .{ }^{1} \mathrm{H} \mathrm{NMR}\left(\mathrm{CDCl}_{3}, 400 \mathrm{MHz}\right) \delta 1.2(\mathrm{~d}, 12 \mathrm{H}), 1.6(\mathrm{~s}$, $3 \mathrm{H}), 1.9(\mathrm{~d}, 3 \mathrm{H}), 2.4-2.5(\mathrm{~m}, 4 \mathrm{H}), 2.7(\mathrm{~m}, 2 \mathrm{H}), 2.8(\mathrm{~m}, 1 \mathrm{H}), 2.9-3.0(\mathrm{~m}, 2 \mathrm{H}), 3.2-3.35(\mathrm{~m}$, $2 \mathrm{H}), 3.45-3.65(\mathrm{~m}, 5 \mathrm{H}), 3.73(\mathrm{~m}, 1 \mathrm{H}), 3.8(\mathrm{~s}, 6 \mathrm{H}), 3.9(\mathrm{~m}, 1 \mathrm{H}), 4.1-4.3(\mathrm{~m}, 3 \mathrm{H}), 4.5(\mathrm{~m}, 1 \mathrm{H})$, 4.8(m, 1H), 6.1(q, 1H), 6.4(t, 1H), 6.85(d, 4H), 7.2-7.5(m, 13H), 7.8(s, 1H), 8.3(d, 2H). Mass calculated 1145.3 Observed 1145.06.

\section{Reference}

1. Divakar K.J. ; Reese, C. B. J. Chem. Soc., Perkin Trans. 1, 1982, 1171-1176. 


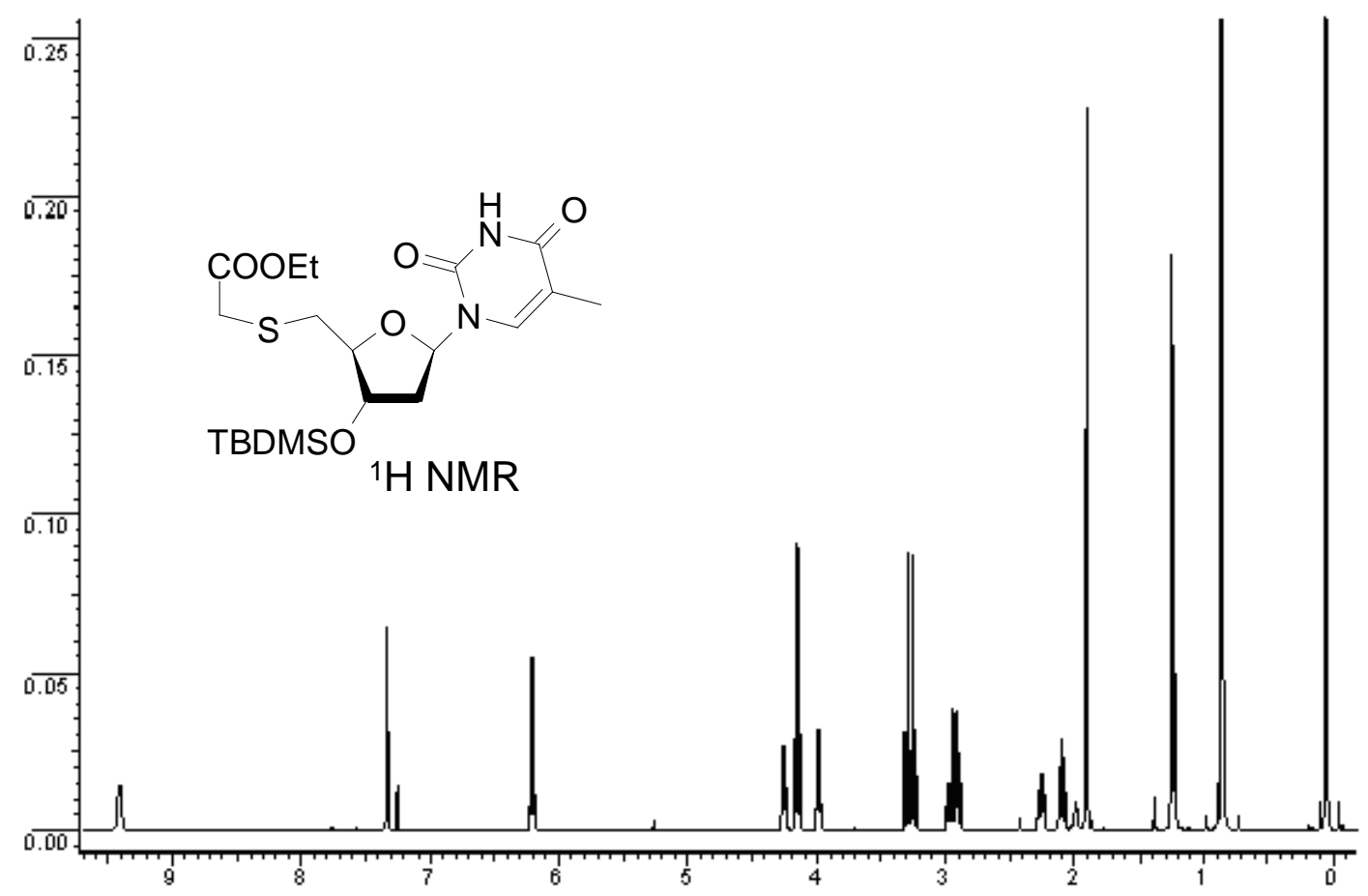

Figure S1 ${ }^{1} \mathrm{H}$ NMR of 3

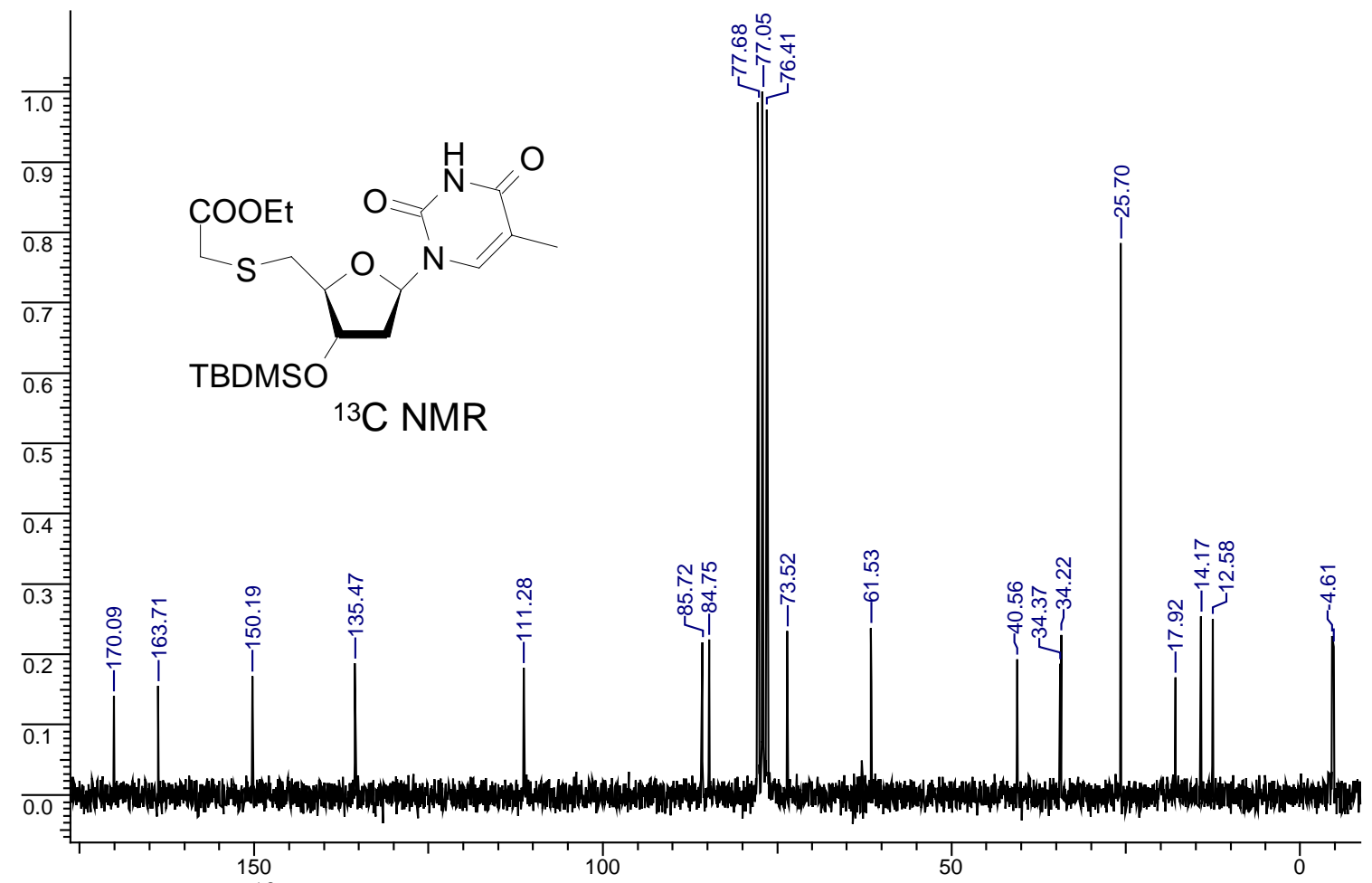

Figure S2 ${ }^{13} \mathrm{C}$ NMR of 3 


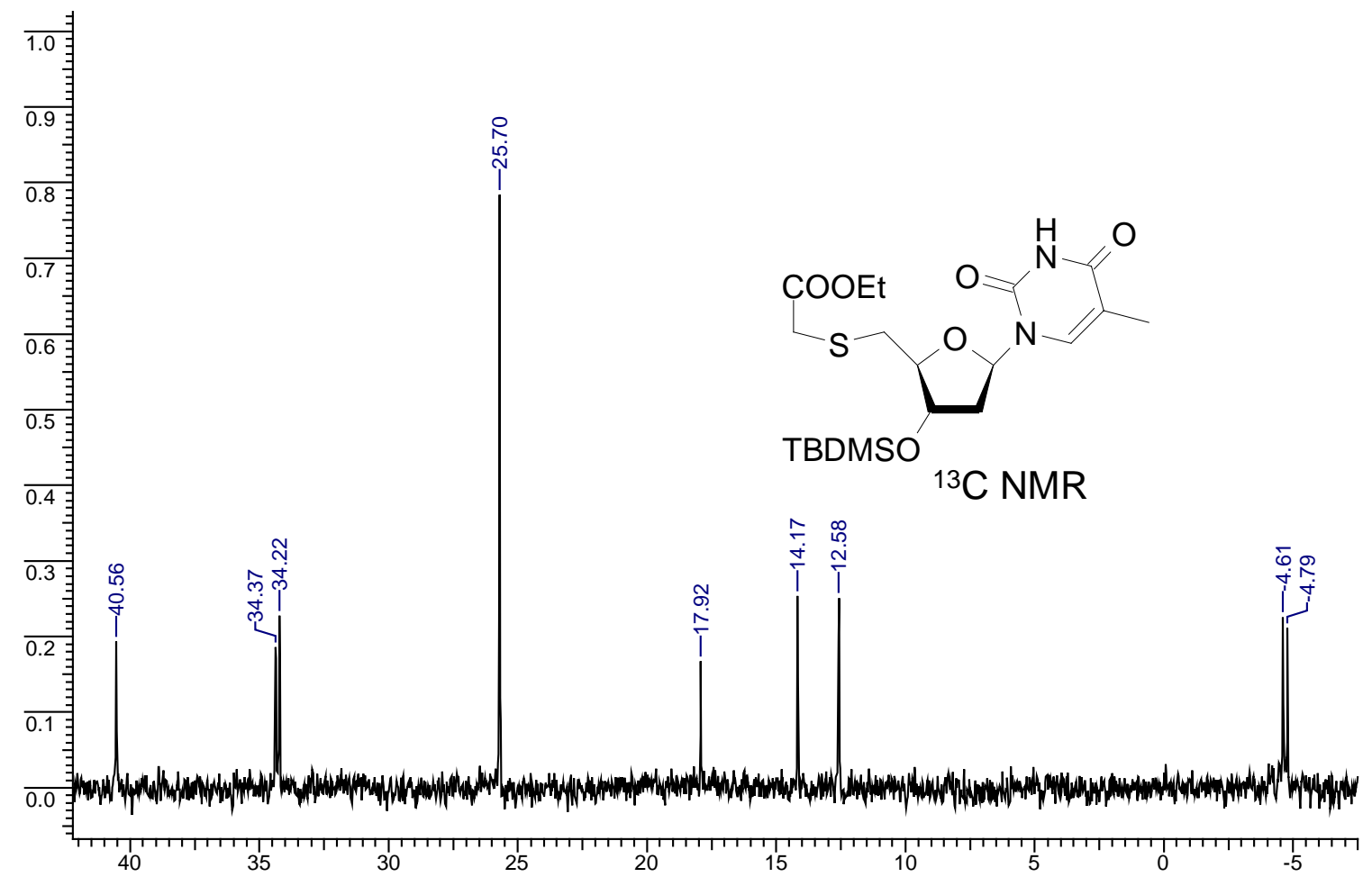

Figure S3: Expanded ${ }^{13} \mathrm{C}$ of $\mathbf{3}$

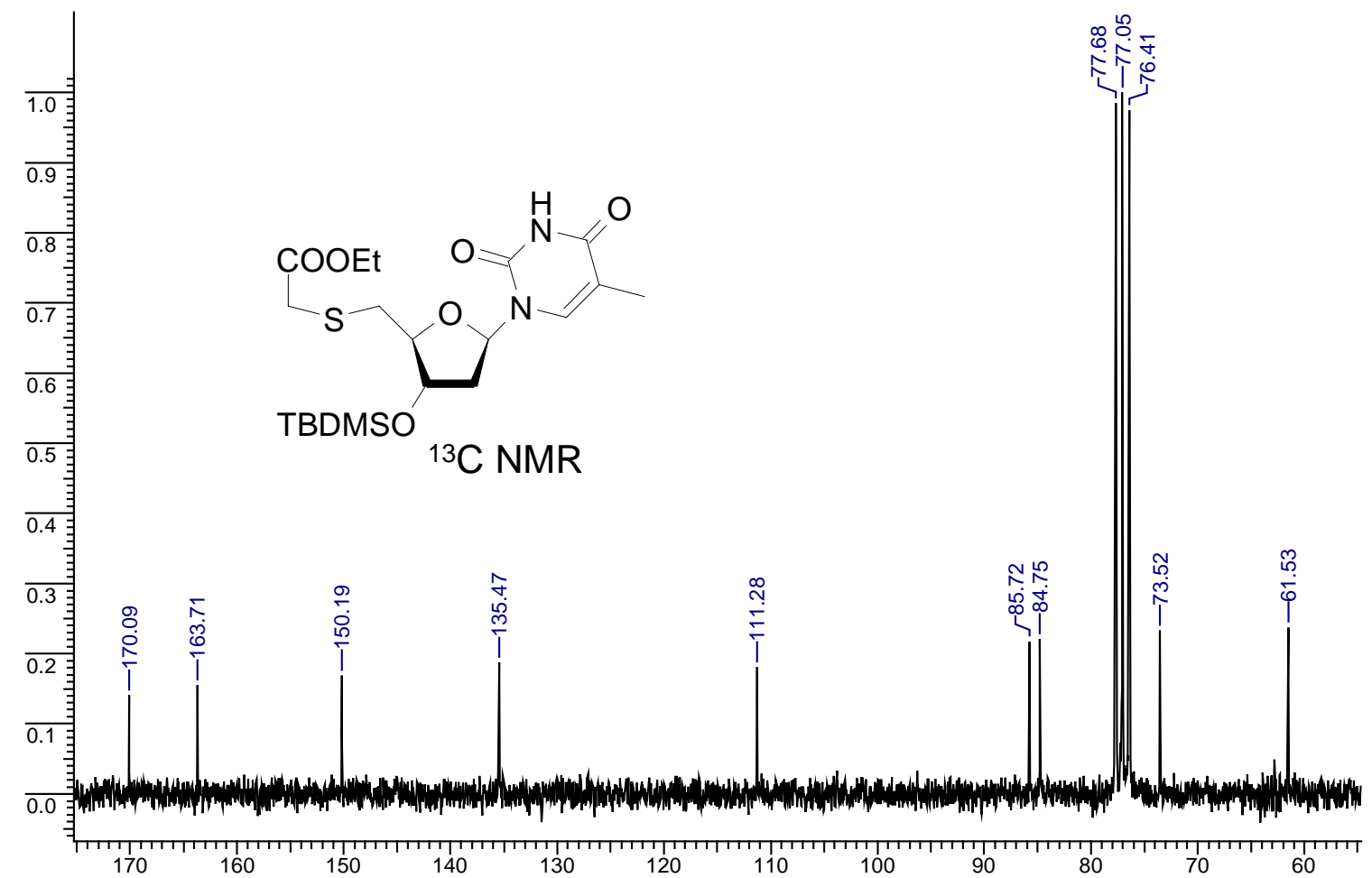

Figure S4: Expanded ${ }^{13} \mathrm{C}$ of $\mathbf{3}$ 


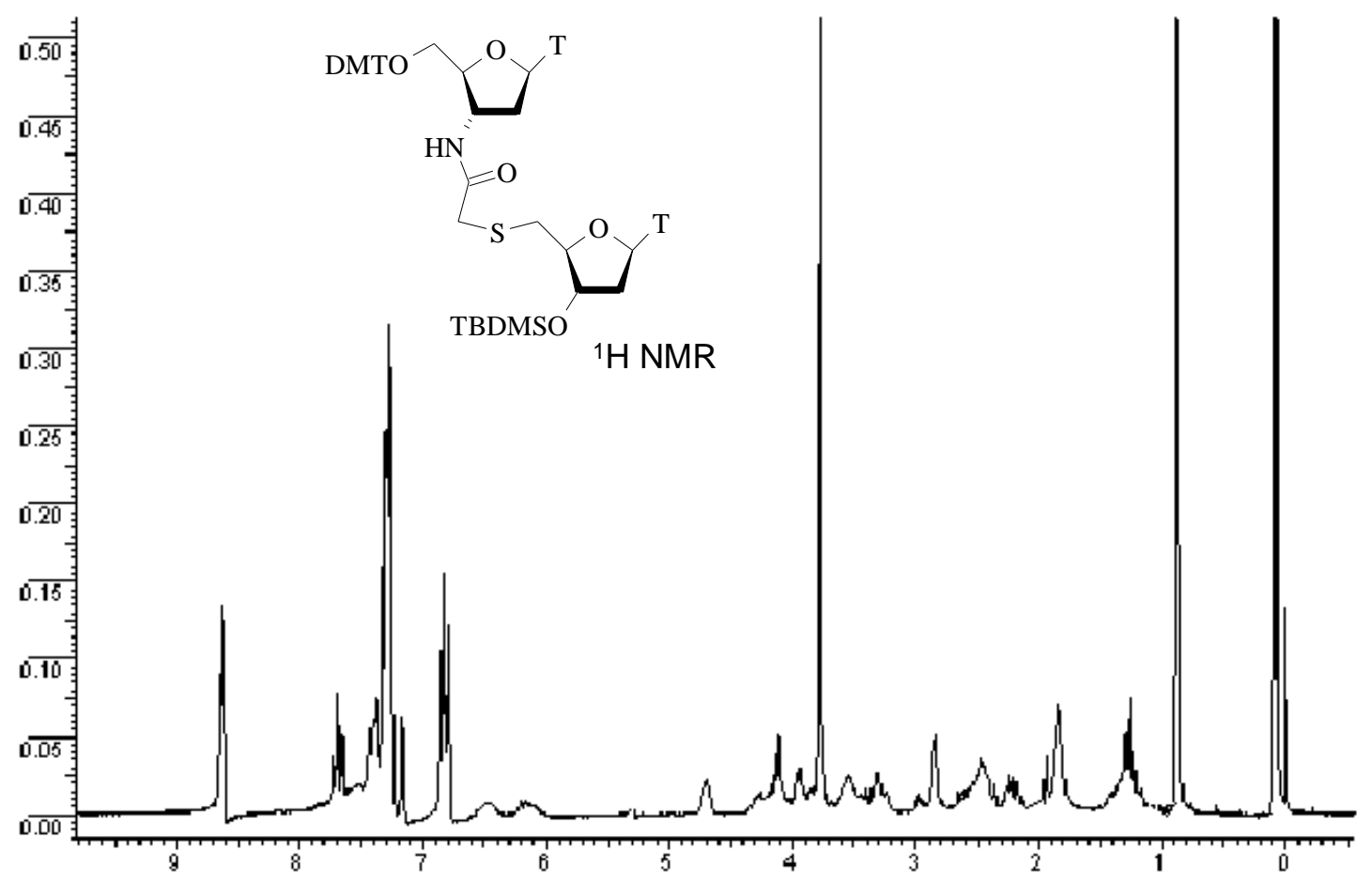

Figure S5: ${ }^{1} \mathrm{H}$ NMR 12

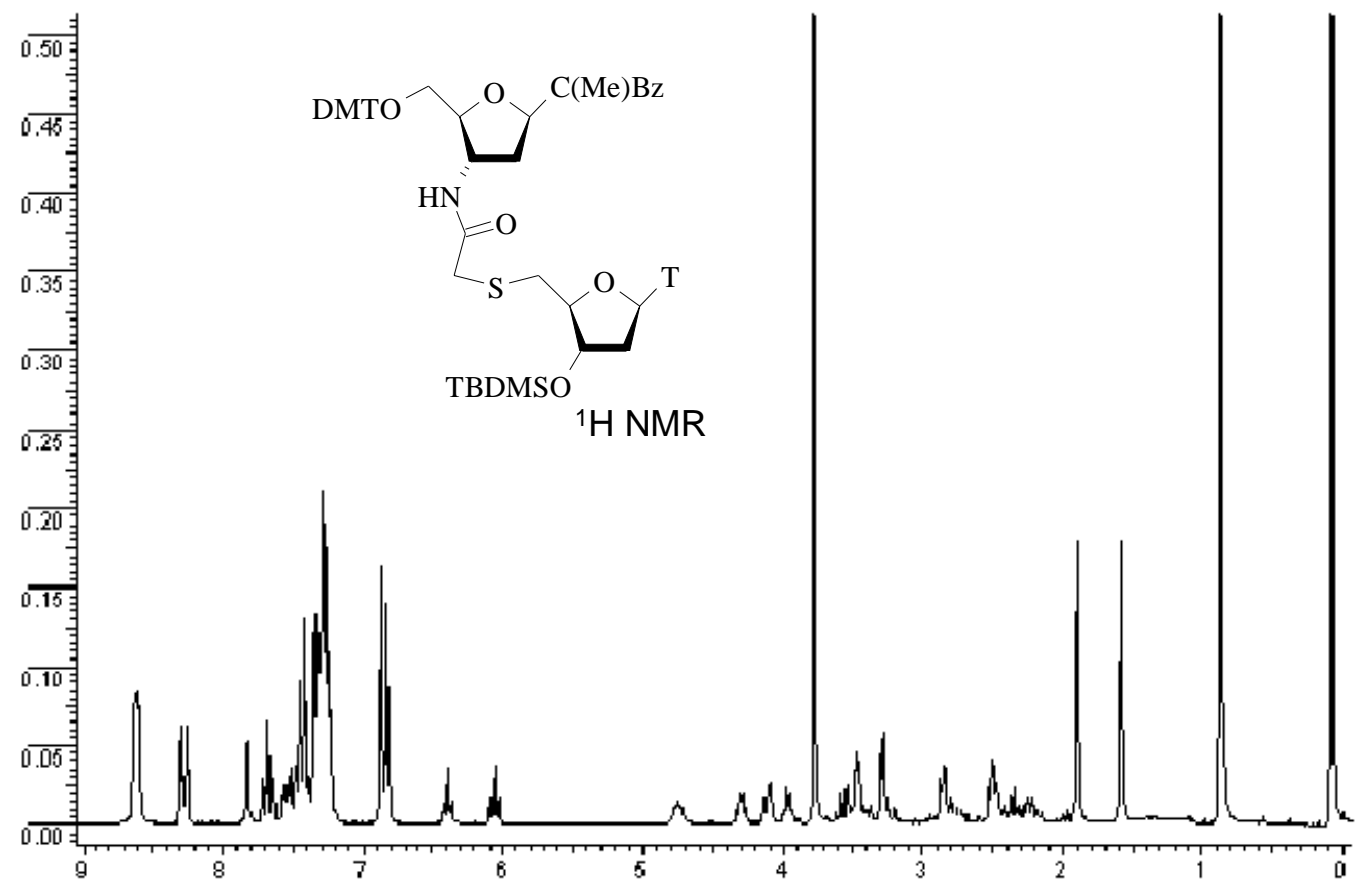

Figure S6: ${ }^{1} \mathrm{H}$ NMR 15 


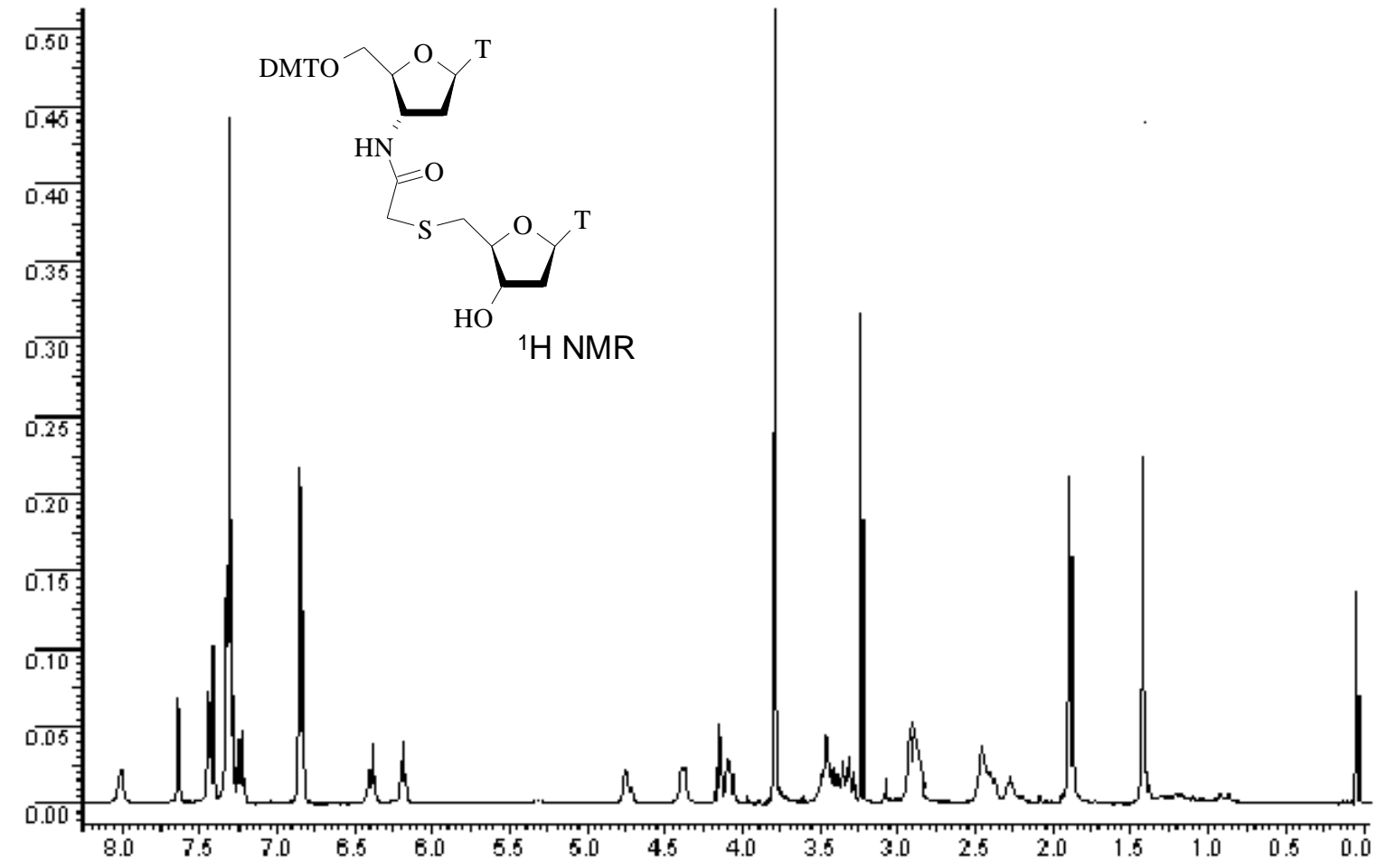

Figure S7: ${ }^{1} \mathrm{H}$ NMR of 13

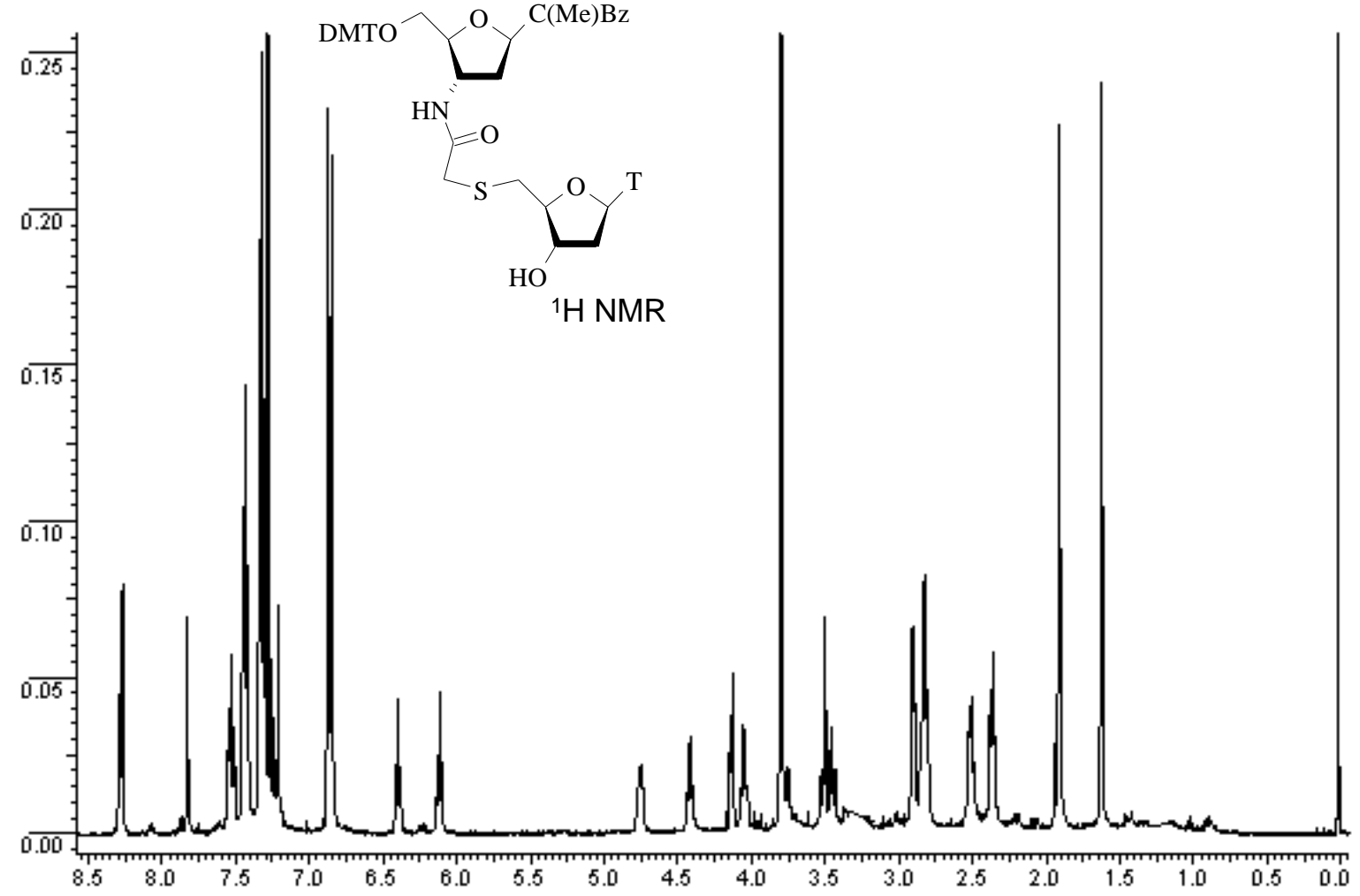

Figure S8: ${ }^{1} \mathrm{H}$ NMR of $\mathbf{1 6}$ 


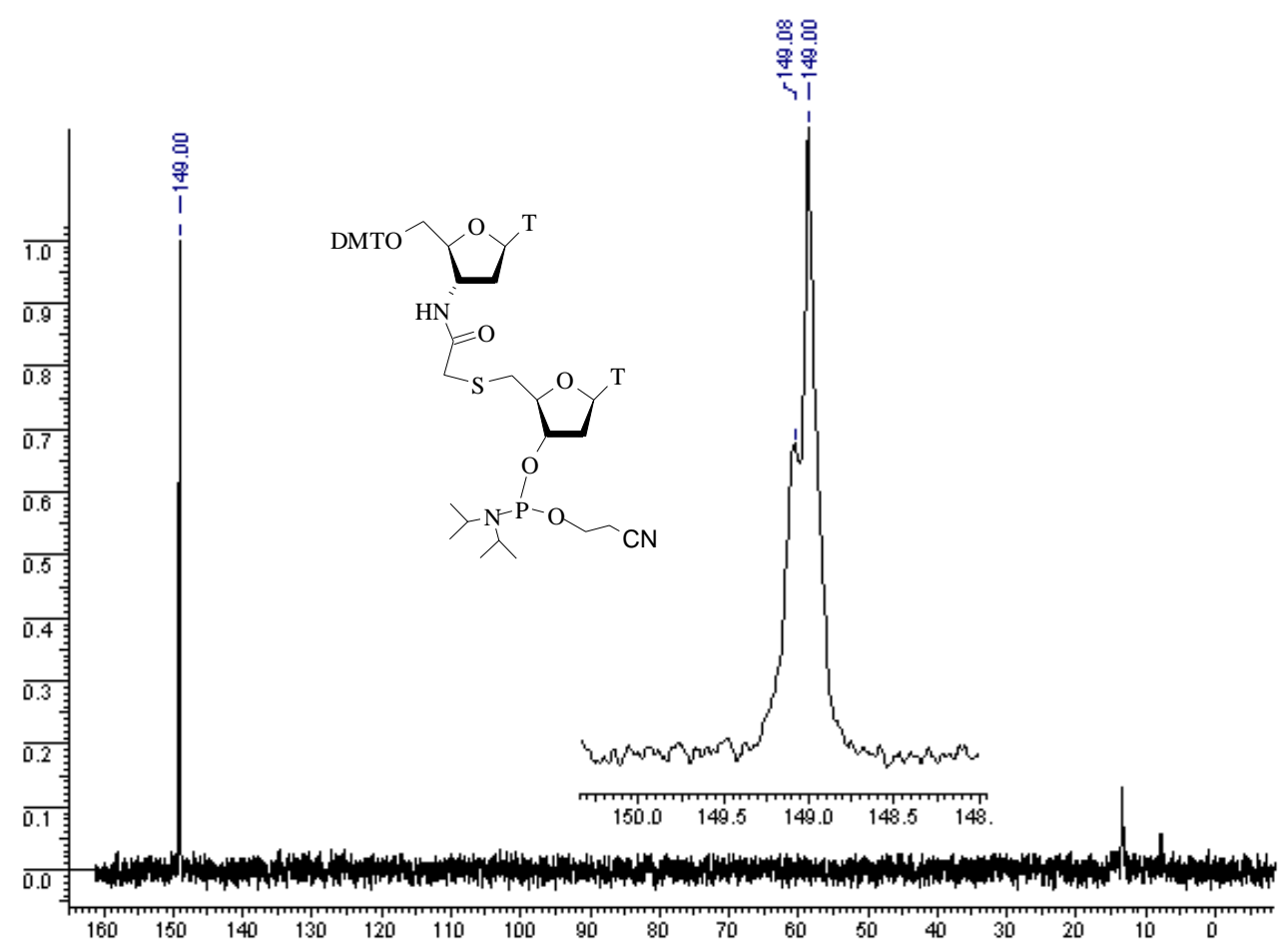

Figure S9: ${ }^{31} \mathrm{P}$ NMR of $\mathbf{1 4}$

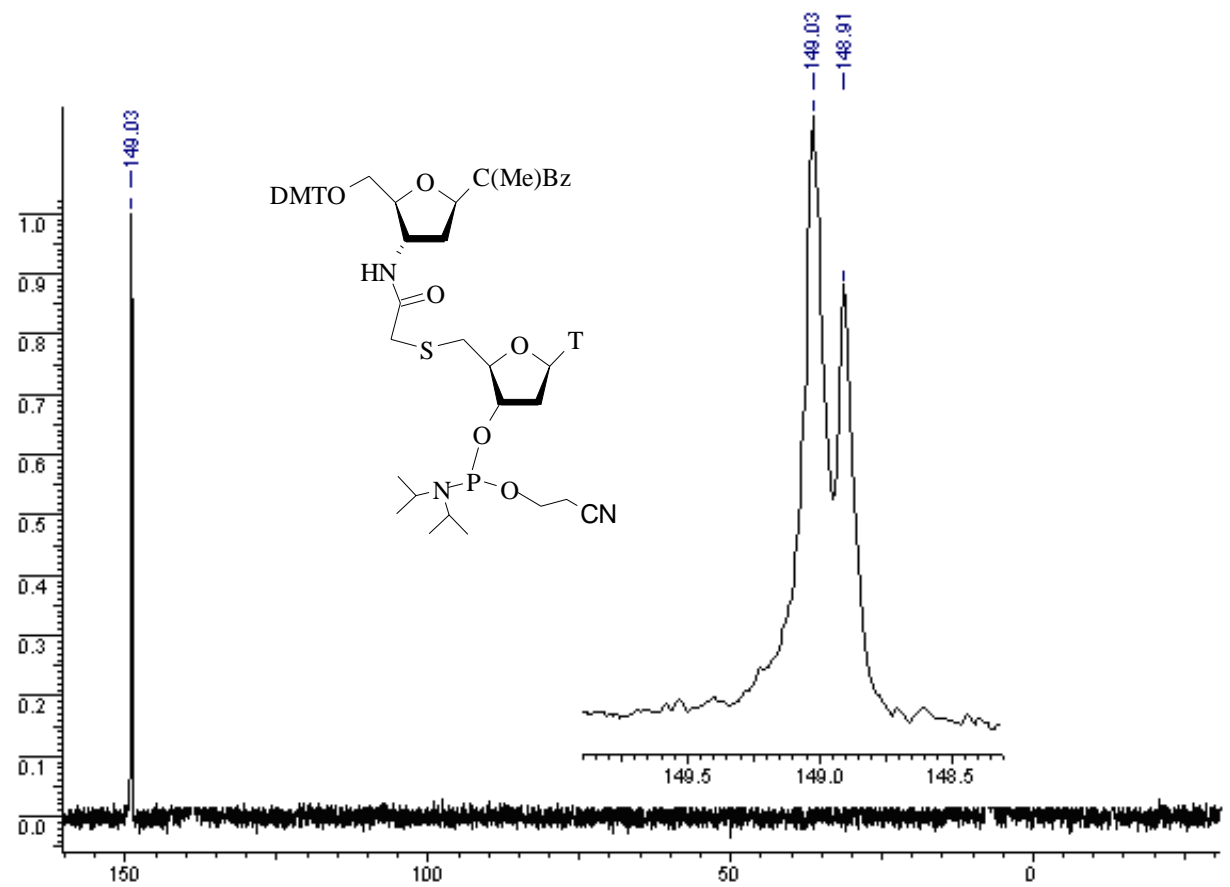

Figure S10: ${ }^{31} \mathrm{P}$ NMR of $\mathbf{1 7}$ 


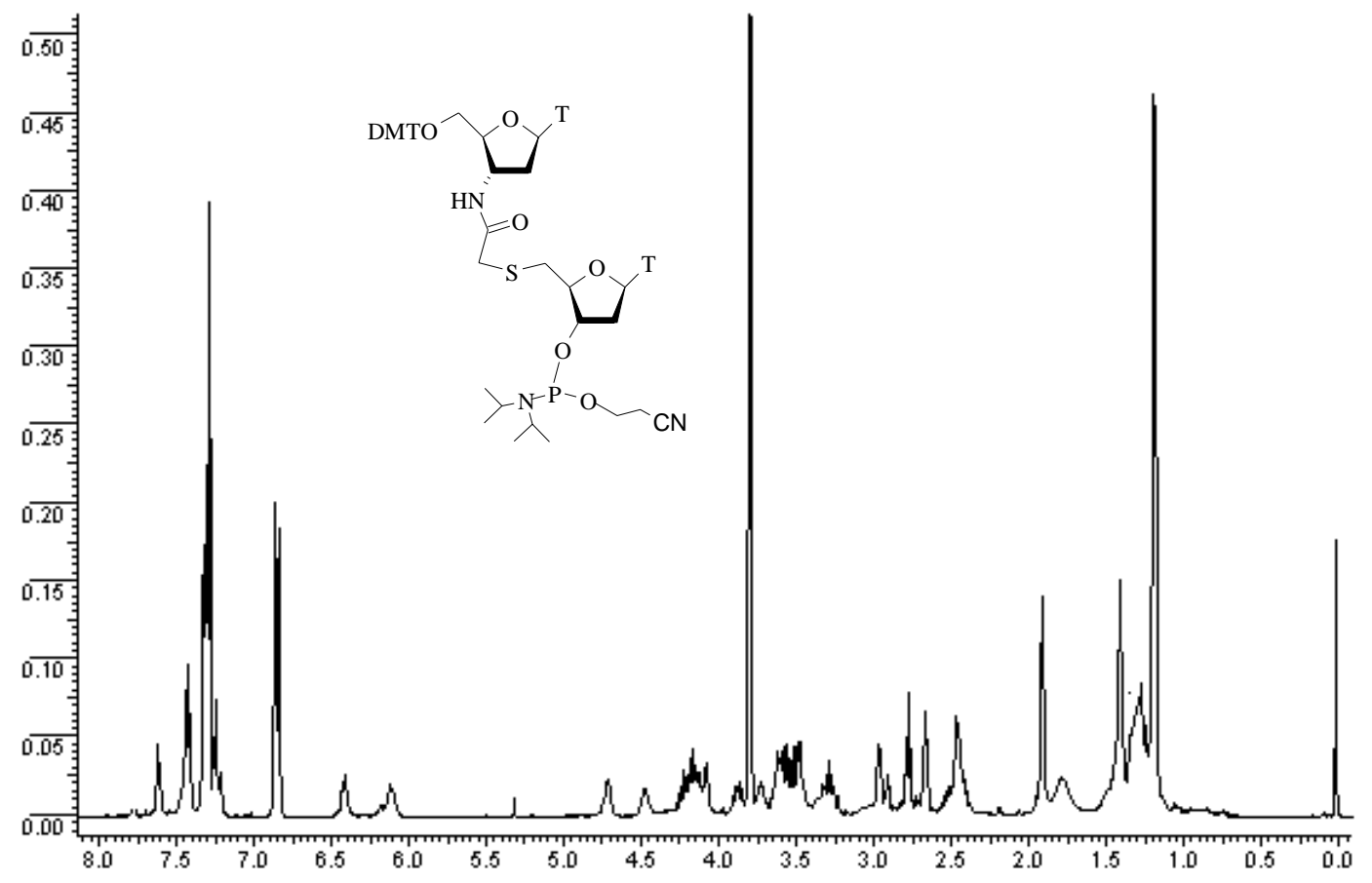

Figure S11: ${ }^{1} \mathrm{H}$ NMR of 14

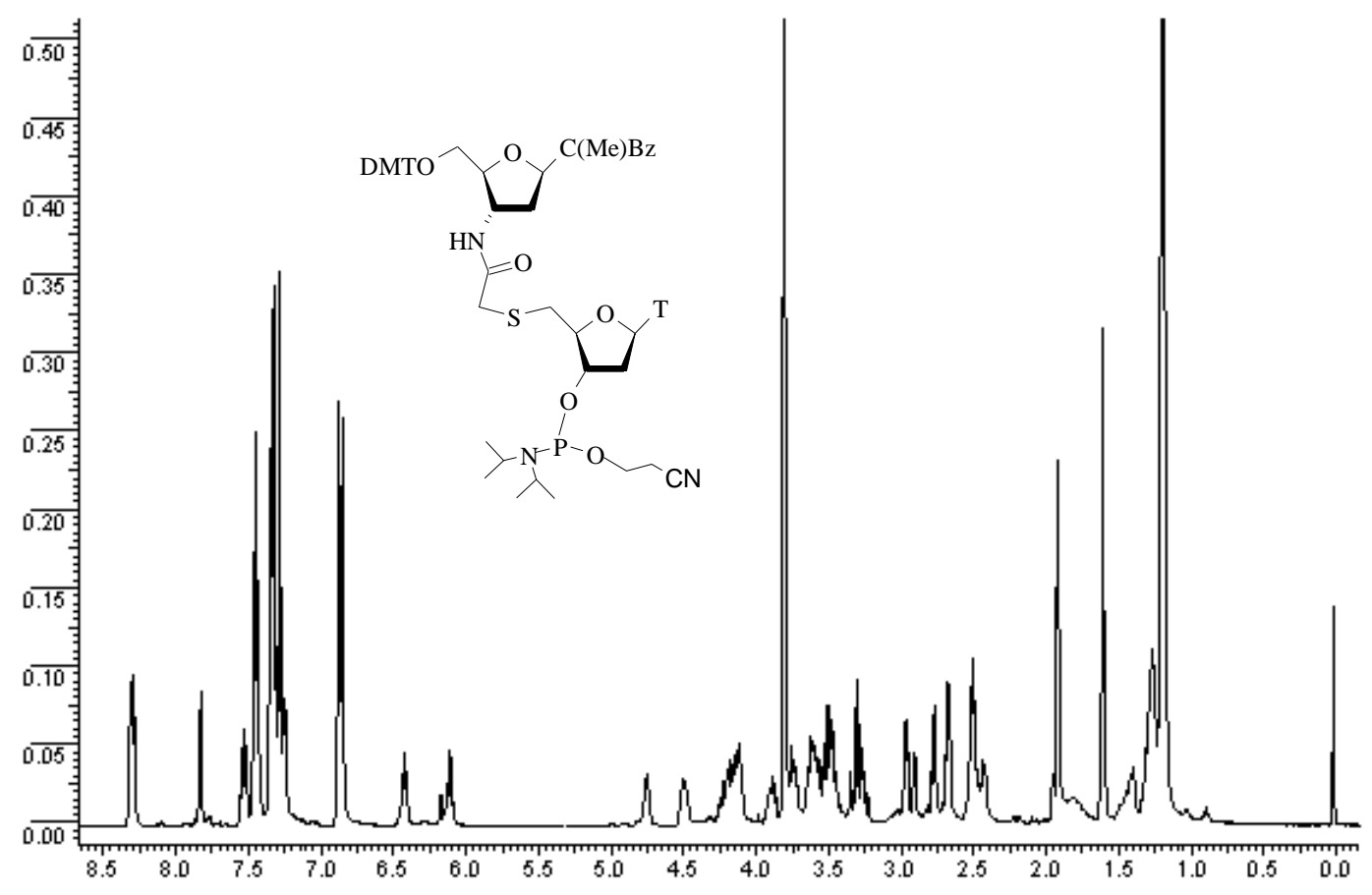

Figure S12: ${ }^{1} \mathrm{H}$ NMR of 17 


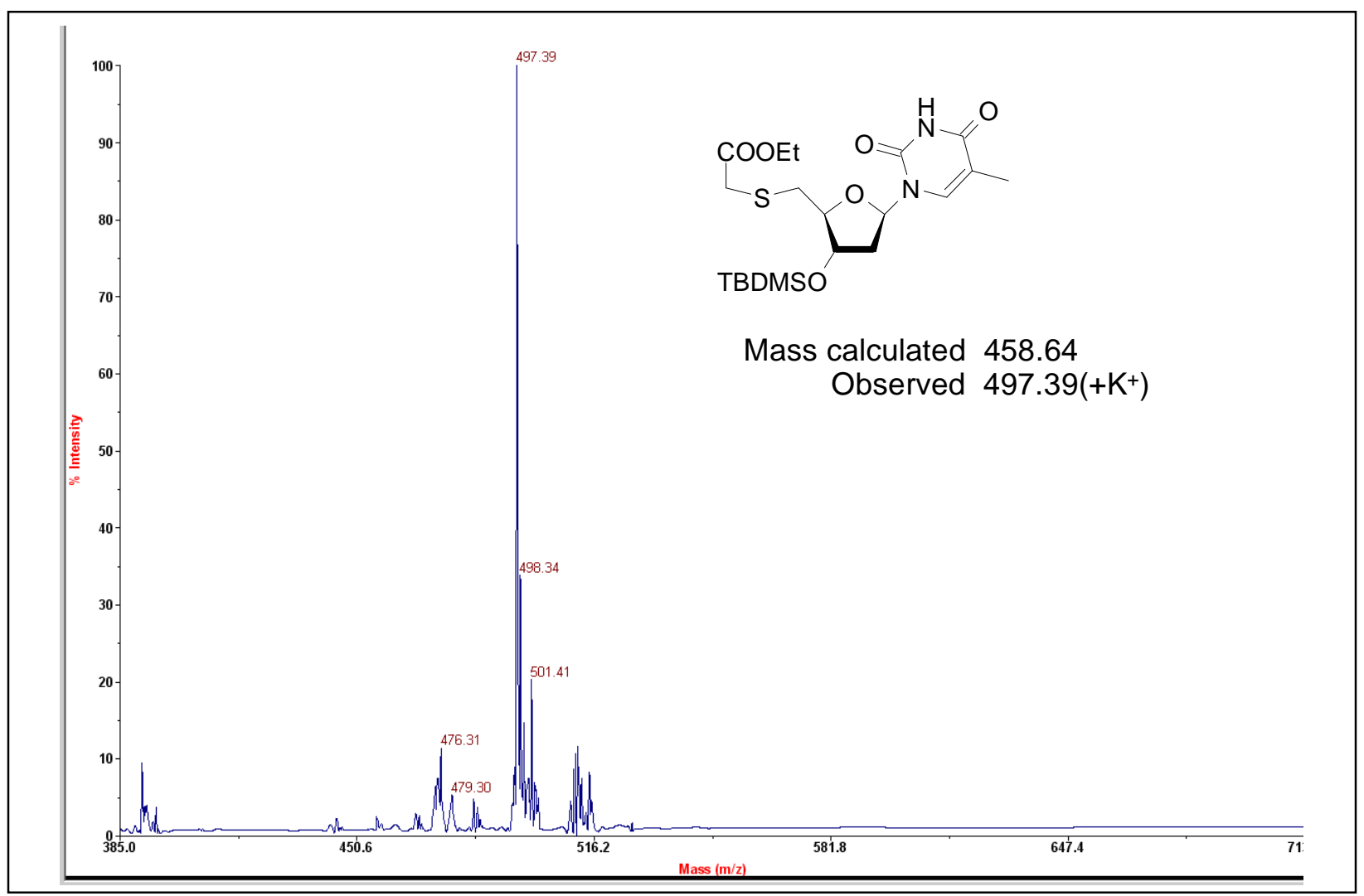

Figure S13: Mass of 3

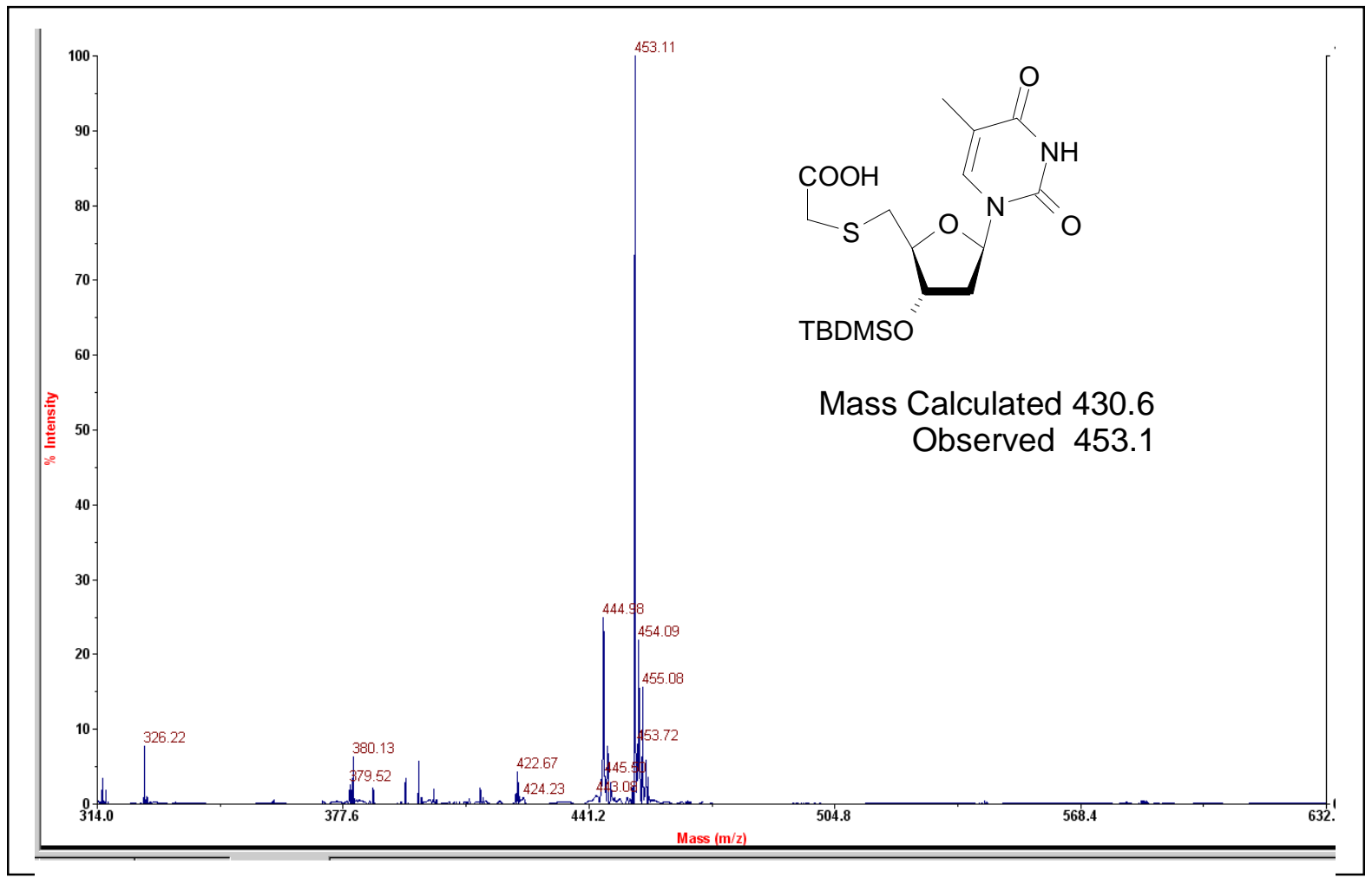


Figure S14: Mass of 4

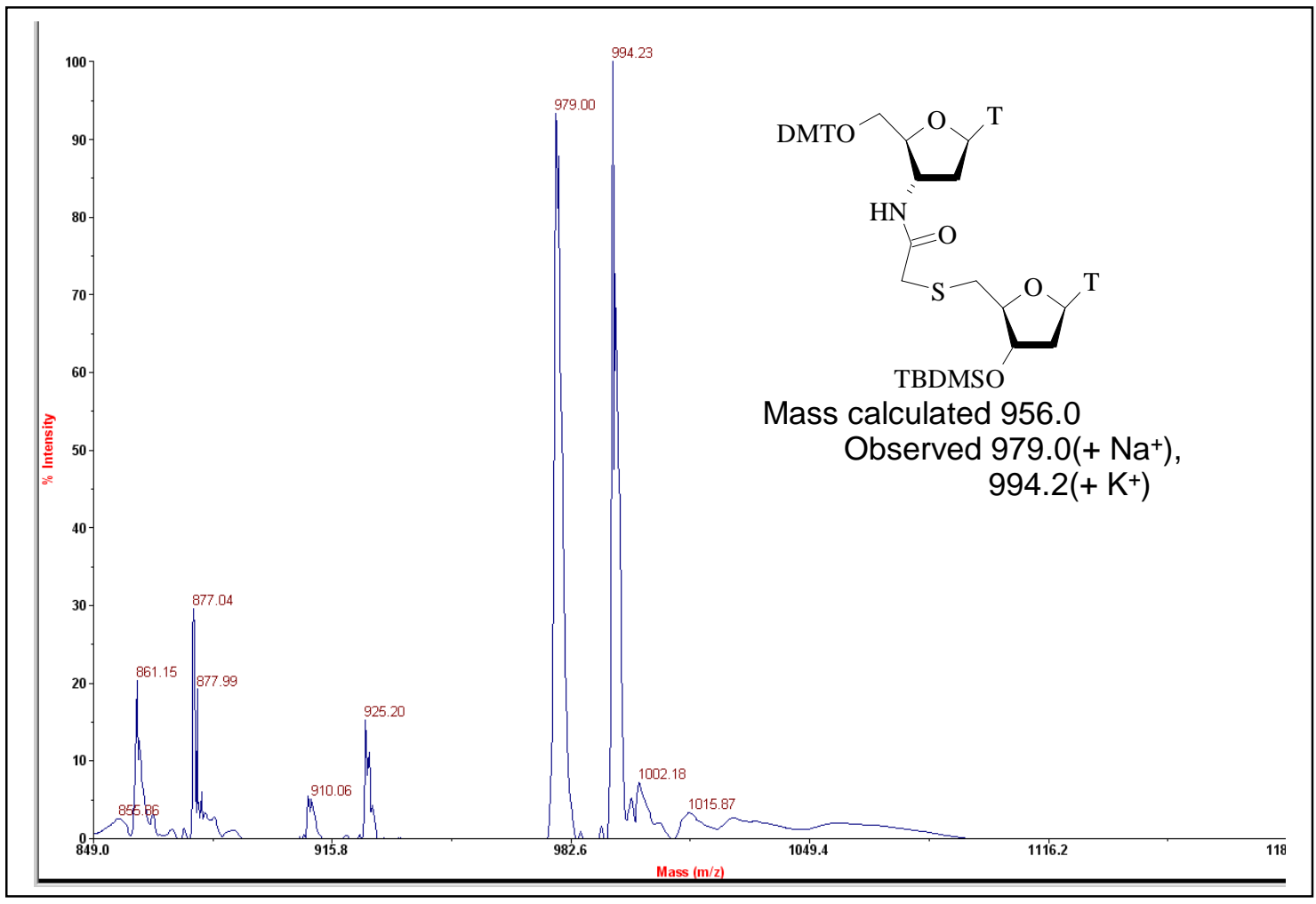

Figure S15: Mass of 12

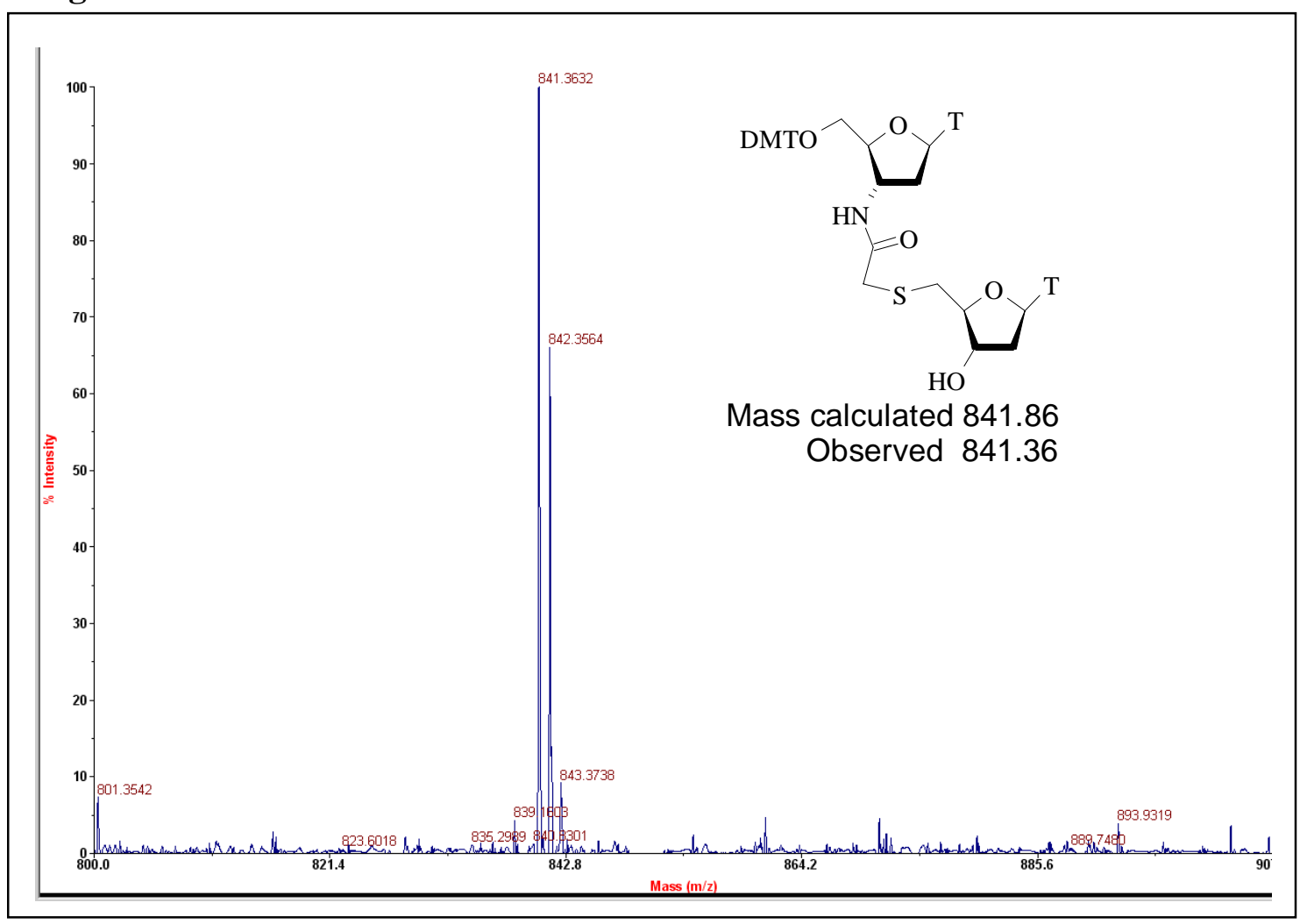


Figure S16: Mass of 13

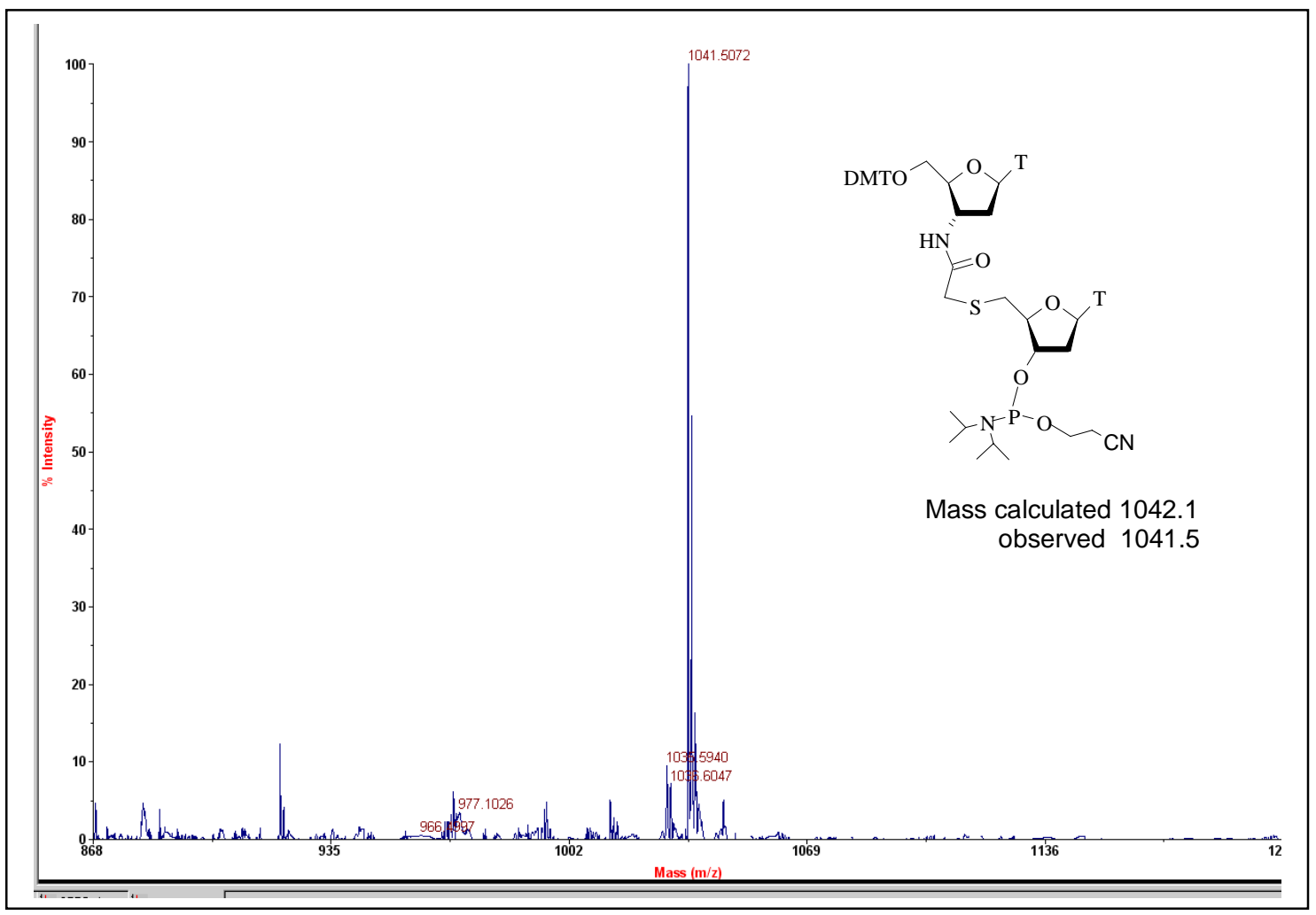

Figure S17: Mass of 14 


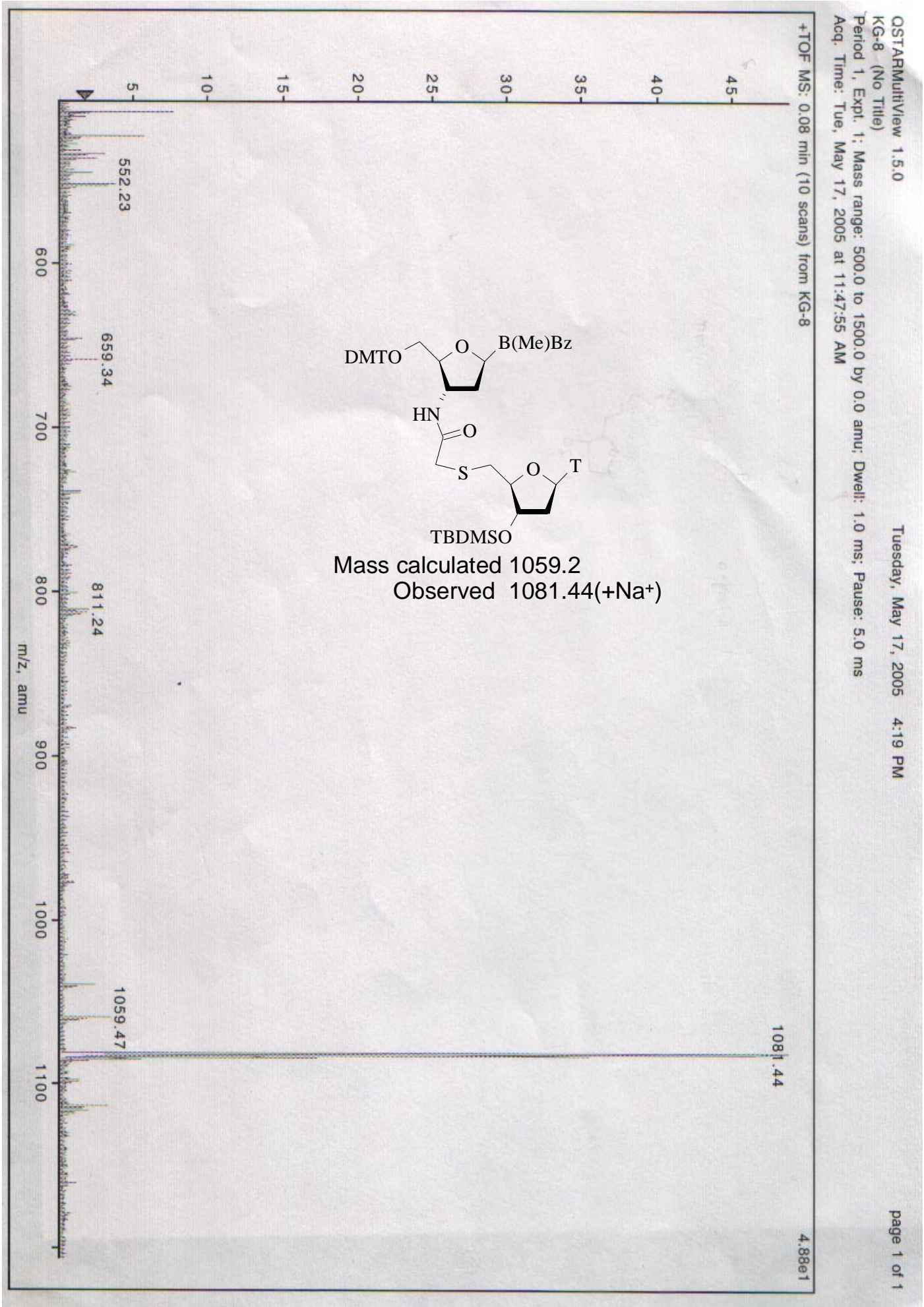

Figure S18: Mass of 15 


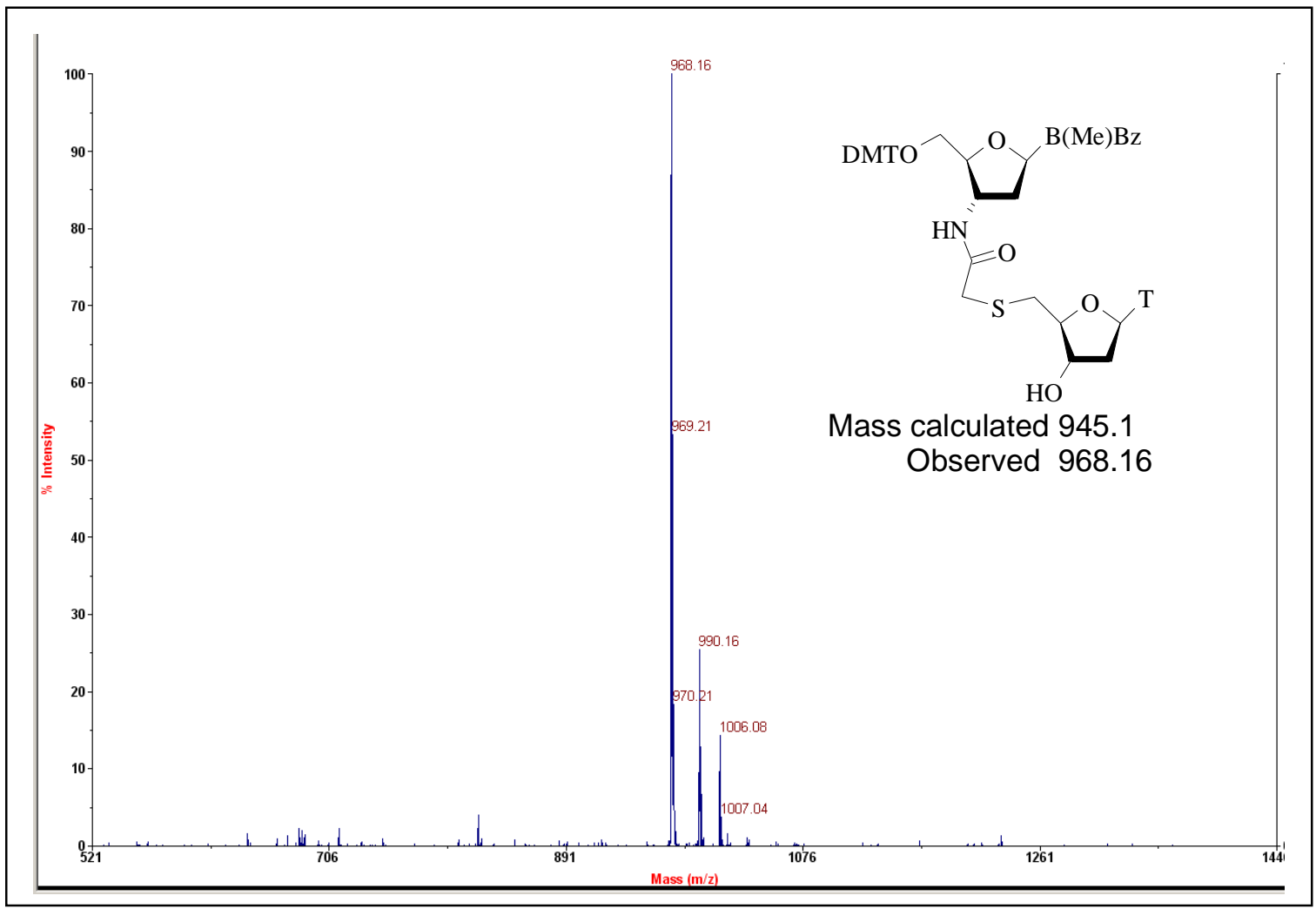

Figure S19: Mass of $\mathbf{1 6}$

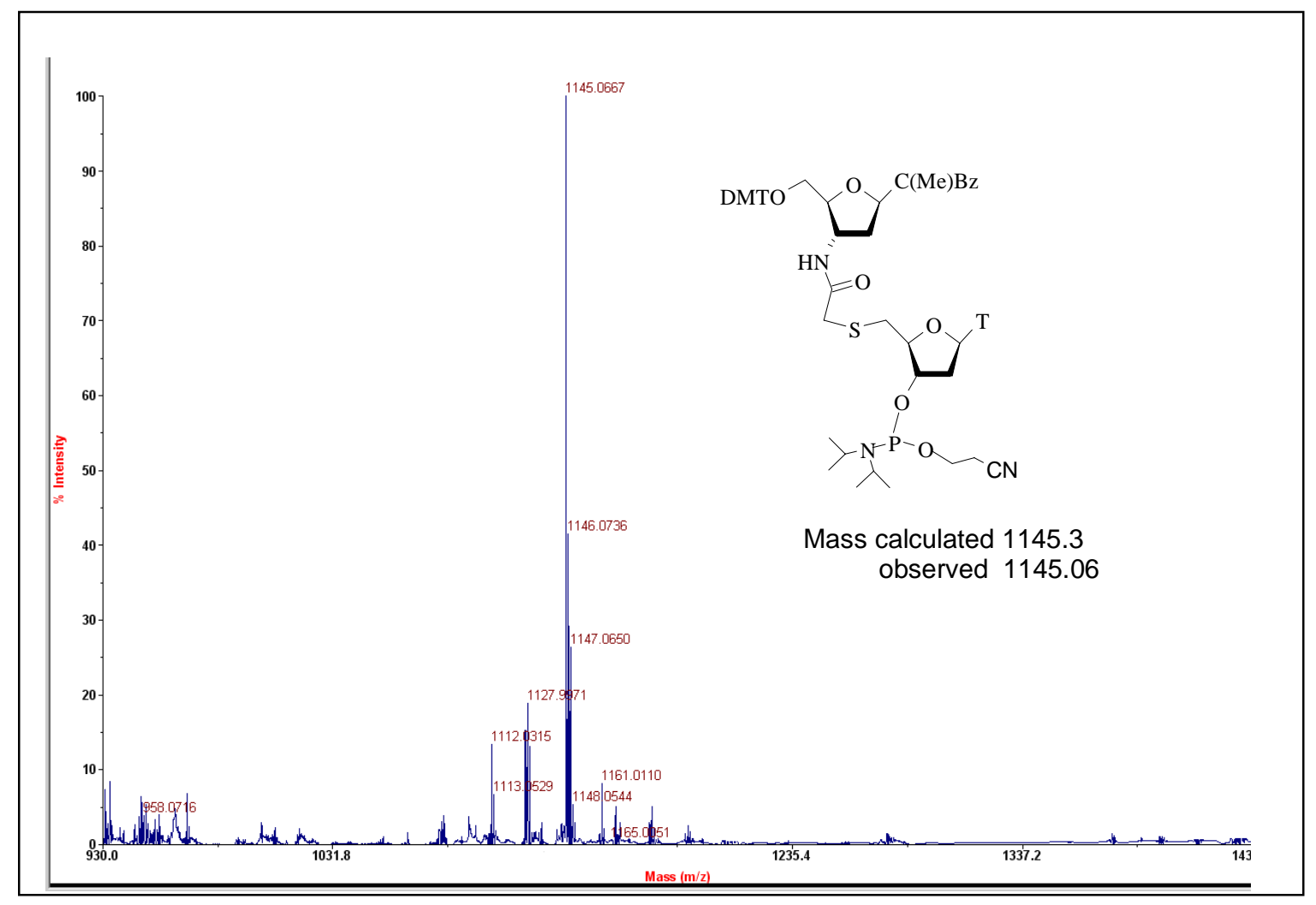

FigureS20: Mass of 17 
TableS1 Conformational study of sugar residues in dinucleoside blocks 18 and 19. pindicates phosphodiester linkage, s- indicates mercaptoacetamide linkage. The 2'-endo conformer population $(\% \mathrm{~S})$ is determined from the sum of the coupling constants of $\mathrm{H} 1$ ' and $\mathrm{H}^{\prime}{ }^{\prime}$ and $\mathrm{H} 2^{\prime \prime}\left({ }^{3} J_{1^{\prime}-2}\right.$, and ${ }^{3} J_{\left.1^{\prime}-2^{\prime}\right)}$. \% S $=\left(\sum \mathrm{H} 1^{\prime}-9.8\right) / 5.9$ where $\sum \mathrm{H}_{1}{ }^{\prime}={ }^{3} J_{1^{\prime}-2^{\prime}}+$ ${ }^{3} J_{1},-2$, , according to Rinkel and Altona. ${ }^{1}$

\begin{tabular}{ccccc}
\hline Dinucleotide & & $\sum \mathrm{H}^{\prime}{ }^{\prime}(\mathrm{Hz})$ & $\% \mathrm{~S}$ & $\begin{array}{c}\text { Predominant Sugar } \\
\text { Ring pucker }\end{array}$ \\
\hline $\mathrm{TpT}^{2}$ & Tp & 13.8 & 68 & $\begin{array}{l}\text { 2'-endo } \\
\text { 2'-endo }\end{array}$ \\
& pT & 13.4 & 61 & \\
\multirow{18}{18}{ (tst) } & ts & 13.6 & 64.4 & 2'-endo \\
& st & 12.5 & 45.8 & 3'-endo/2'-endo \\
& & & & \\
$\mathbf{1 9}(\mathrm{cst})$ & cs & 13.2 & 57.6 & 2'-endo \\
& st & 13.3 & 59.3 & 2'-endo \\
\hline
\end{tabular}

1. Rinkel, L. J.; Altona, C. J. Biomol.Struct. Dyn. 1987, 4, 621-649

2. Nawrot, B.; Boczkowska, M.; Wojcik, M.; Sochaki, M.; Kazmierski, S.; Stec, W.J. Nucleic Acids Res. 1998, 26, 2650-2658 
A
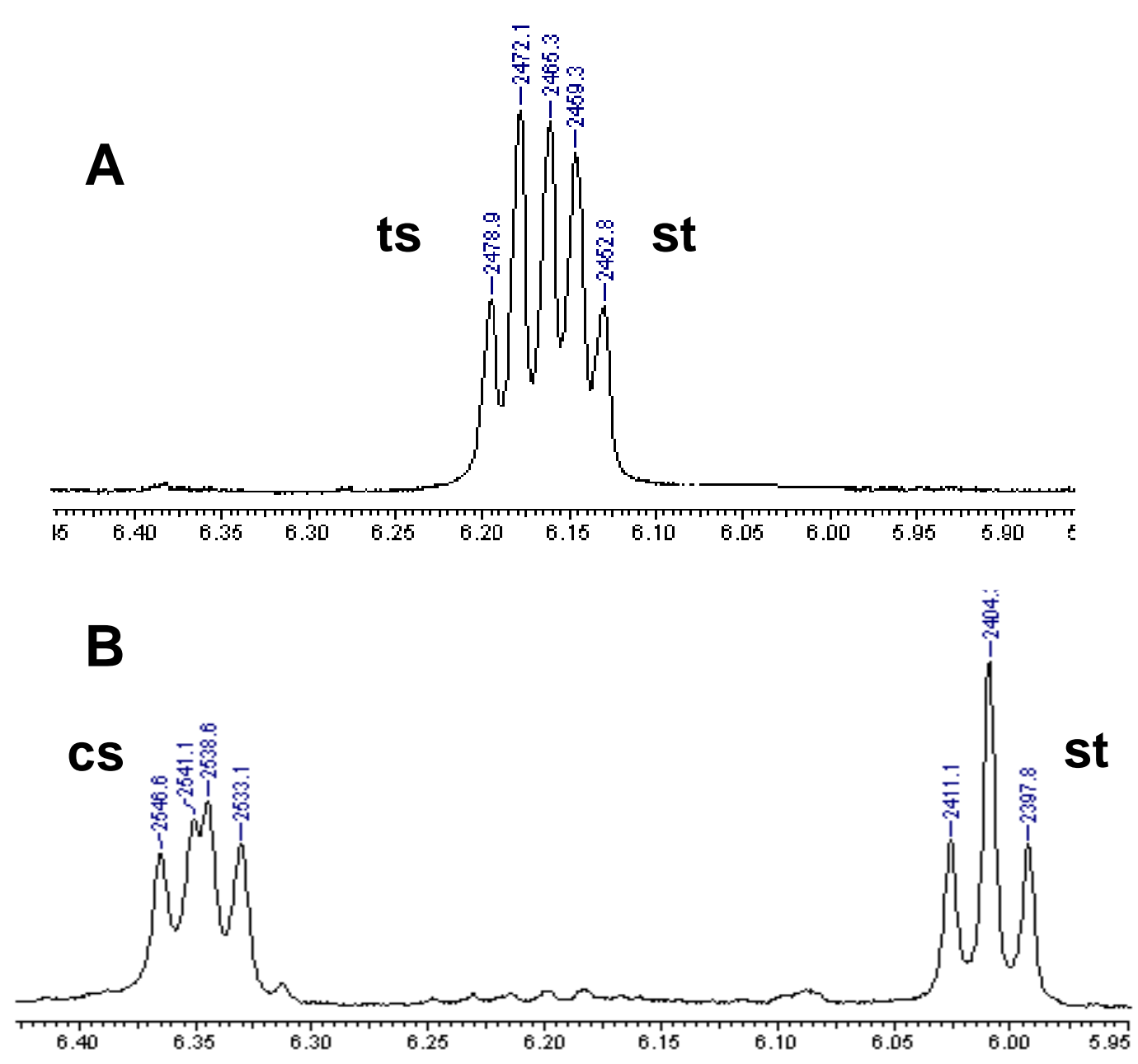

FigureS21: H1' region of ${ }^{1} \mathrm{H}$ NMR spectra of A. 18(tst) and B. 19(cst) at $25^{\circ} \mathrm{C} .5^{\prime}$ terminal ribose $\mathrm{H} 1$ ' signals are downfield of 3'-terminal ribose $\mathrm{H} 1$ ' signals. 


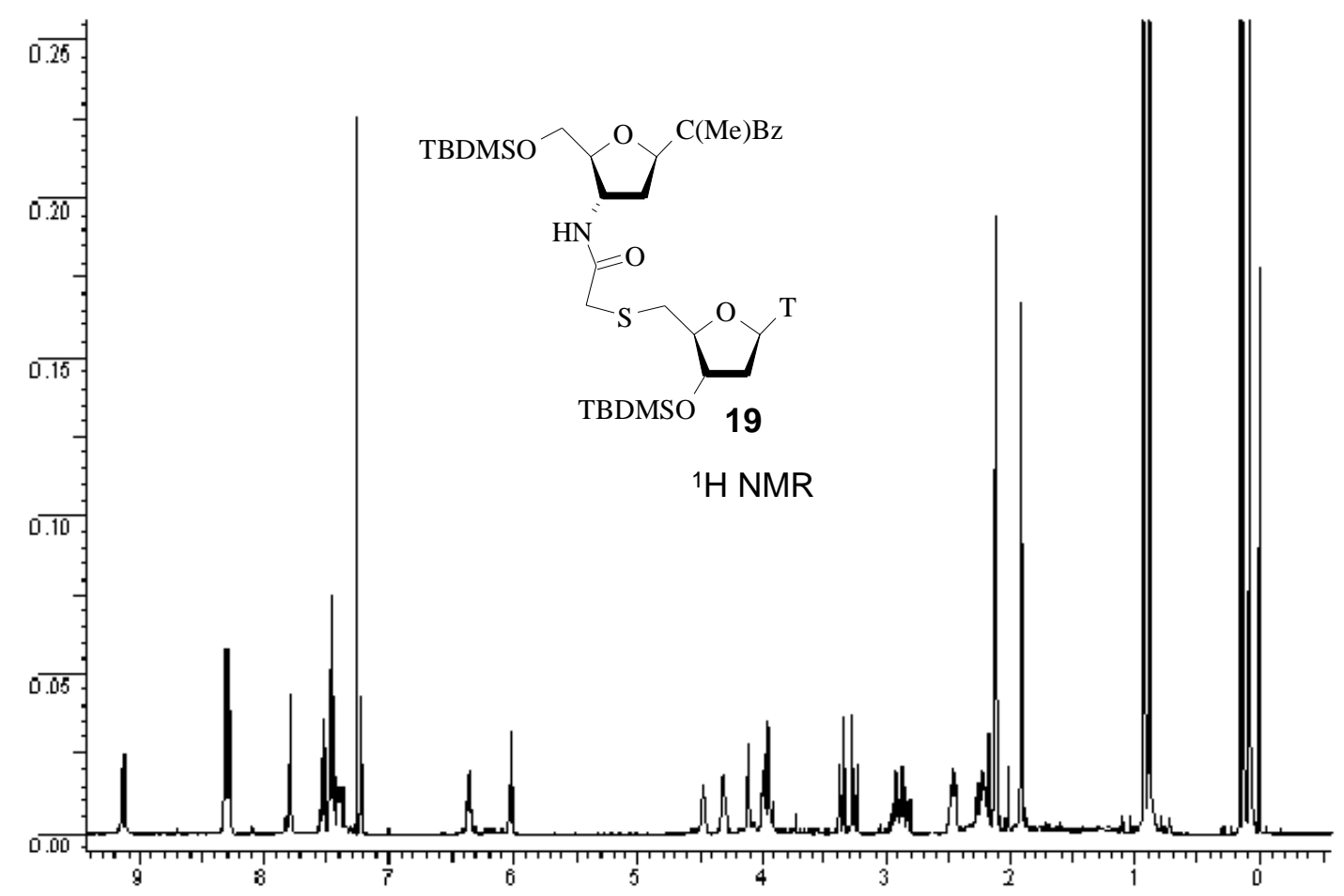

Figure S22: ${ }^{1} \mathrm{H}$ NMR of 19

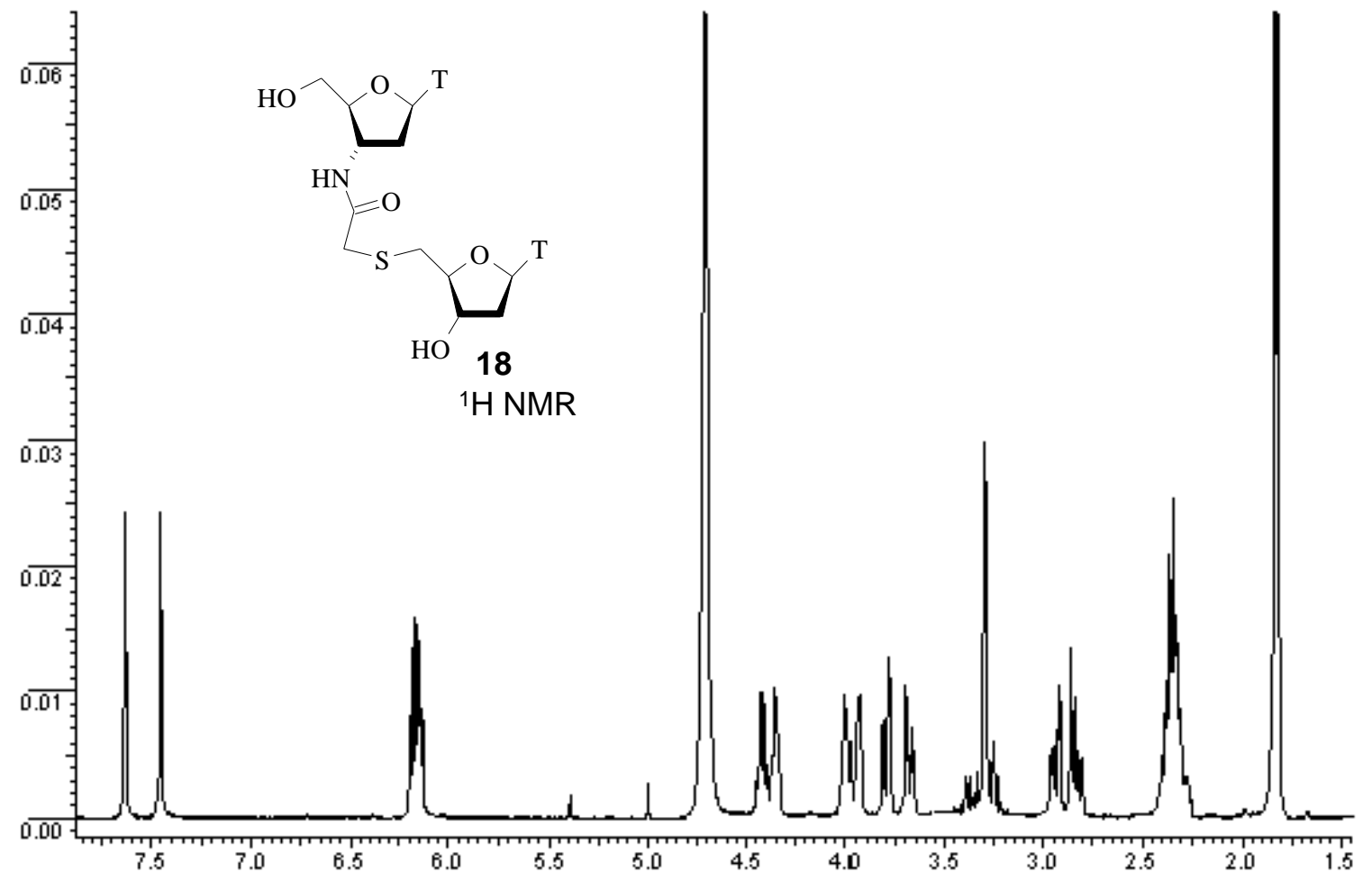

Figure S23: ${ }^{1} \mathrm{H}$ NMR of $\mathbf{1 8}$ 
Oligomer Synthesis: The oligomers were synthesized on an Applied Biosystems 3900 DNA Synthesizer at $40 \mathrm{nmol}$ scale. Dinucleotide phosphoramidites 14 and 17 were used as solution in acetonitrile at concentration of 0.1-0.15 M. Purification of all the oligonucleotides was carried out by RP-HPLC C18 colunm .

MALDI-TOF Mass spectral analysis was performed on a Voyager-De-STR (Applied Biosystems) MALDI-TOF. A nitrogen laser $(337 \mathrm{~nm})$ was used for desorption and ionization. Spectra were acquired in linear mode. The matrix used for analysis was THAP (Trihydroxy acetophenone) and diammonium citrate as additive.

Table S2. Oligomers synthesized, their HPLC $t_{R}$ and MALDI-TOF mass characterization

\begin{tabular}{|c|c|c|c|}
\hline Entry & Sequence & $\mathrm{HPLCt}_{\mathrm{R}}(\mathrm{min})$ & Mass calc/observed \\
\hline 1 & 5' CG TTtstTTT TGC 3' 20 & 7.9 & $3606.54 / 3606.64$ \\
\hline 2 & 5' CGTT tst TT tst GC 3' 21 & 8.3 & $3596.64 / 5597.01$ \\
\hline 3 & $5^{\prime} \mathrm{CG}$ tst tst tst tst GC 3' 22 & 9.2 & $3576.86 / 3576.65$ \\
\hline 4 & $5^{\prime}$ TCT C tst TCT T 3' 23 & 8.6 & $2933.16 / 2933.16$ \\
\hline 5 & 5' TCT C tst TC tst 3' 24 & 9.2 & $2923.26 / 2924.06$ \\
\hline 6 & 5' CCT C tst ACC TCA G TT ACA 3' 26 & 8.9 & $5366.78 / 5366.88$ \\
\hline 7 & 5' CCT C tst ACC TCA G tst ACA 3' 27 & 9.3 & $5356.9 / 5356.92$ \\
\hline 8 & 5' Test CTT TCTT 3' 29 & 8.0 & $2948.2 / 2948.1$ \\
\hline 9 & 5' Test CTT Test T 3' 30 & 8.8 & 2938.3/2938.77 \\
\hline 10 & 5' Test cst T Test T 3, 31 & 9.0 & $2928.4 / 2928.7$ \\
\hline 11 & 5' TCA cst A GAT G 3' 32 & 8.3 & $3036.26 / 3037.0$ \\
\hline
\end{tabular}




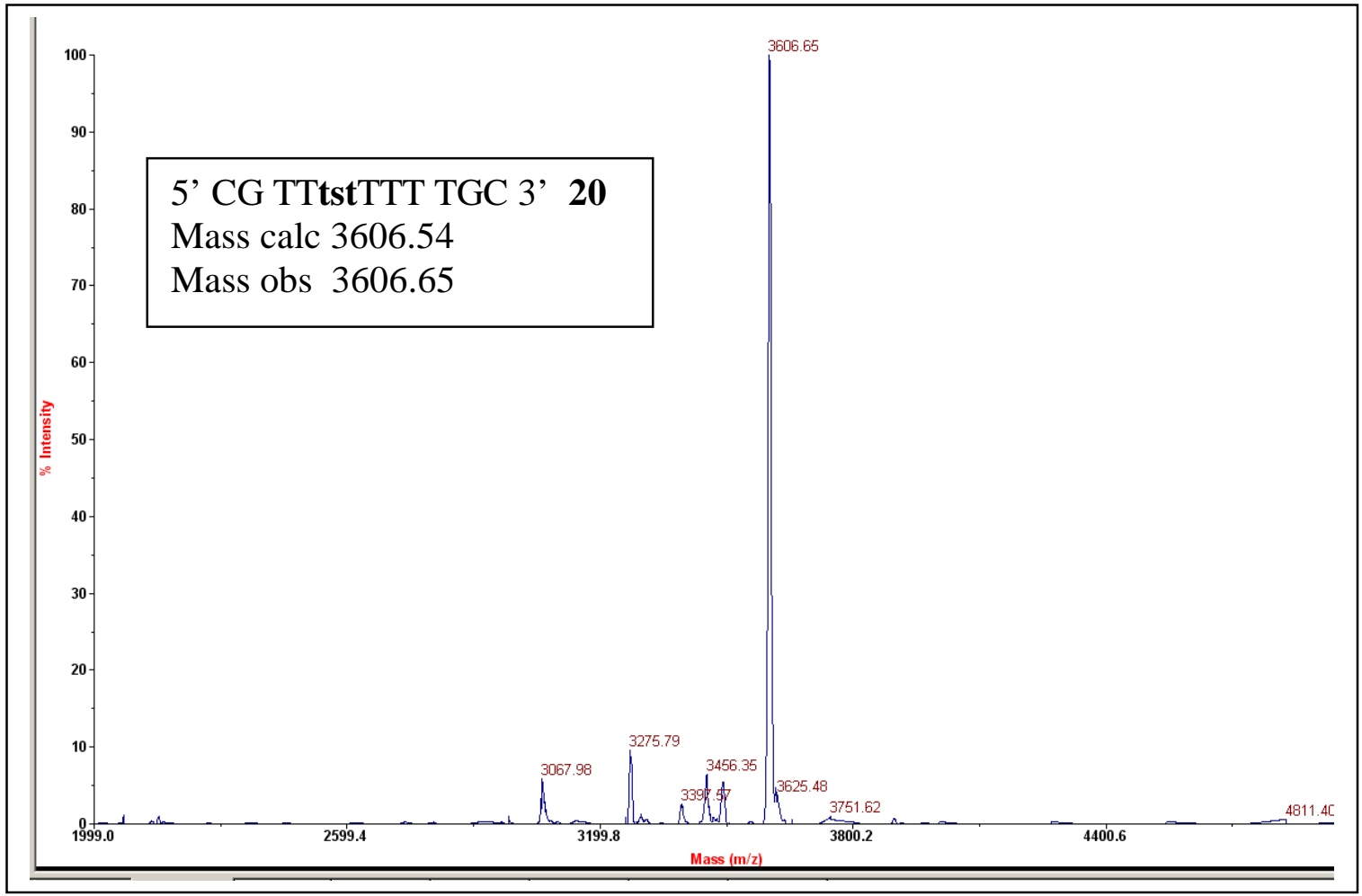

Figure S24: MALDI-TOF mass of $\mathbf{2 0}$

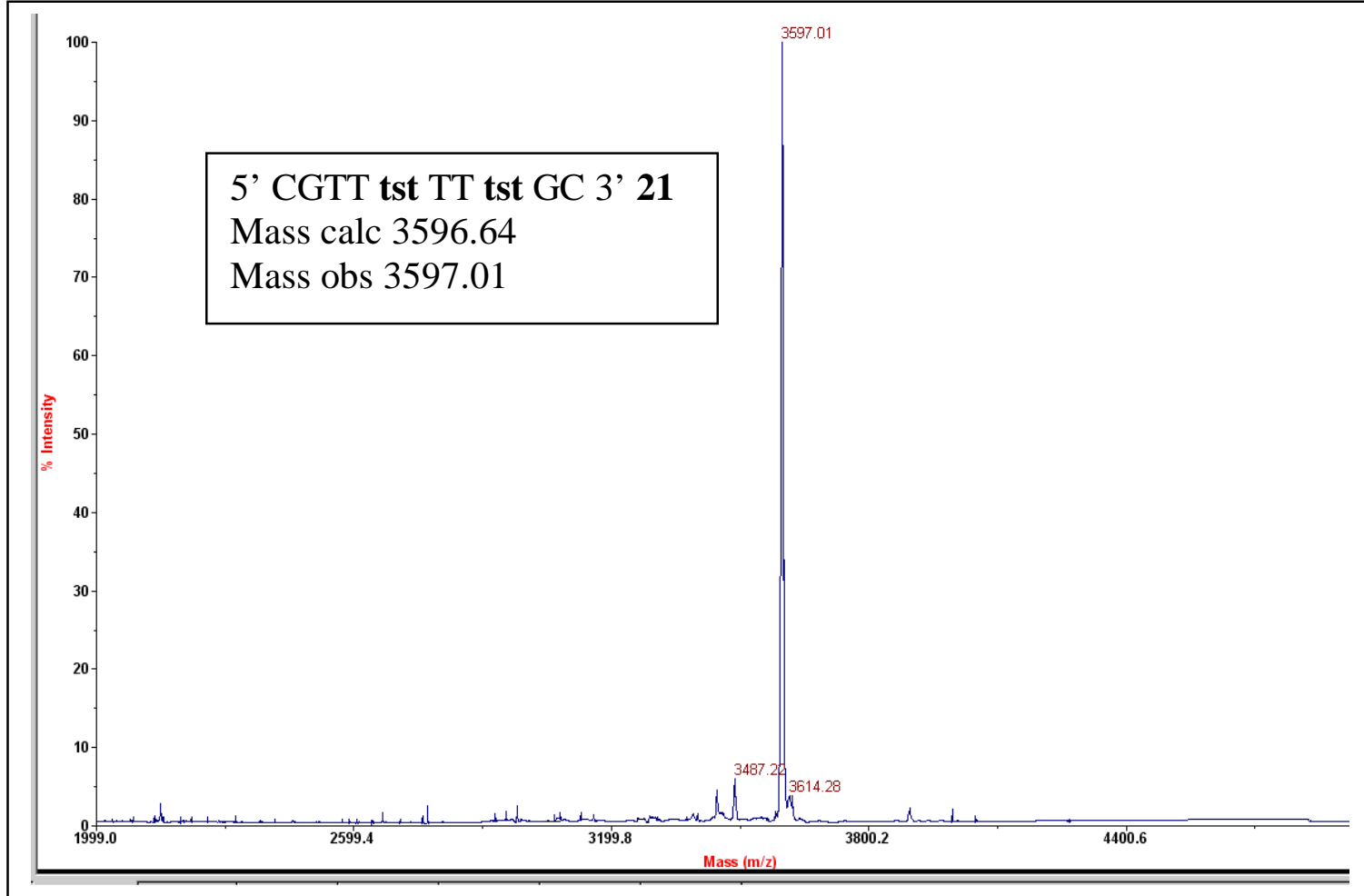

Figure S25: MALDI-TOF mass of 21 


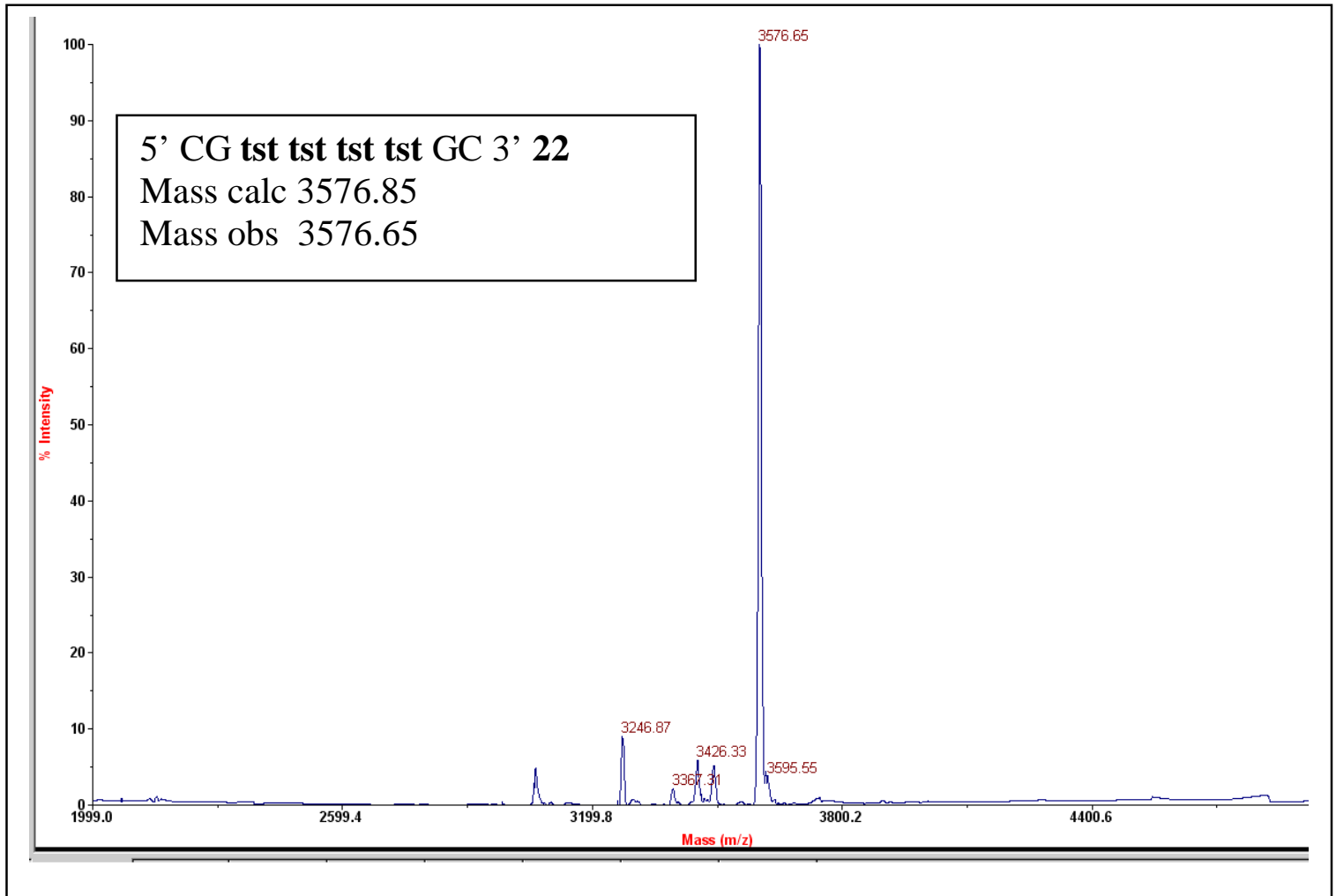

Figure S26: MALDI-TOF mass of $\mathbf{2 2}$

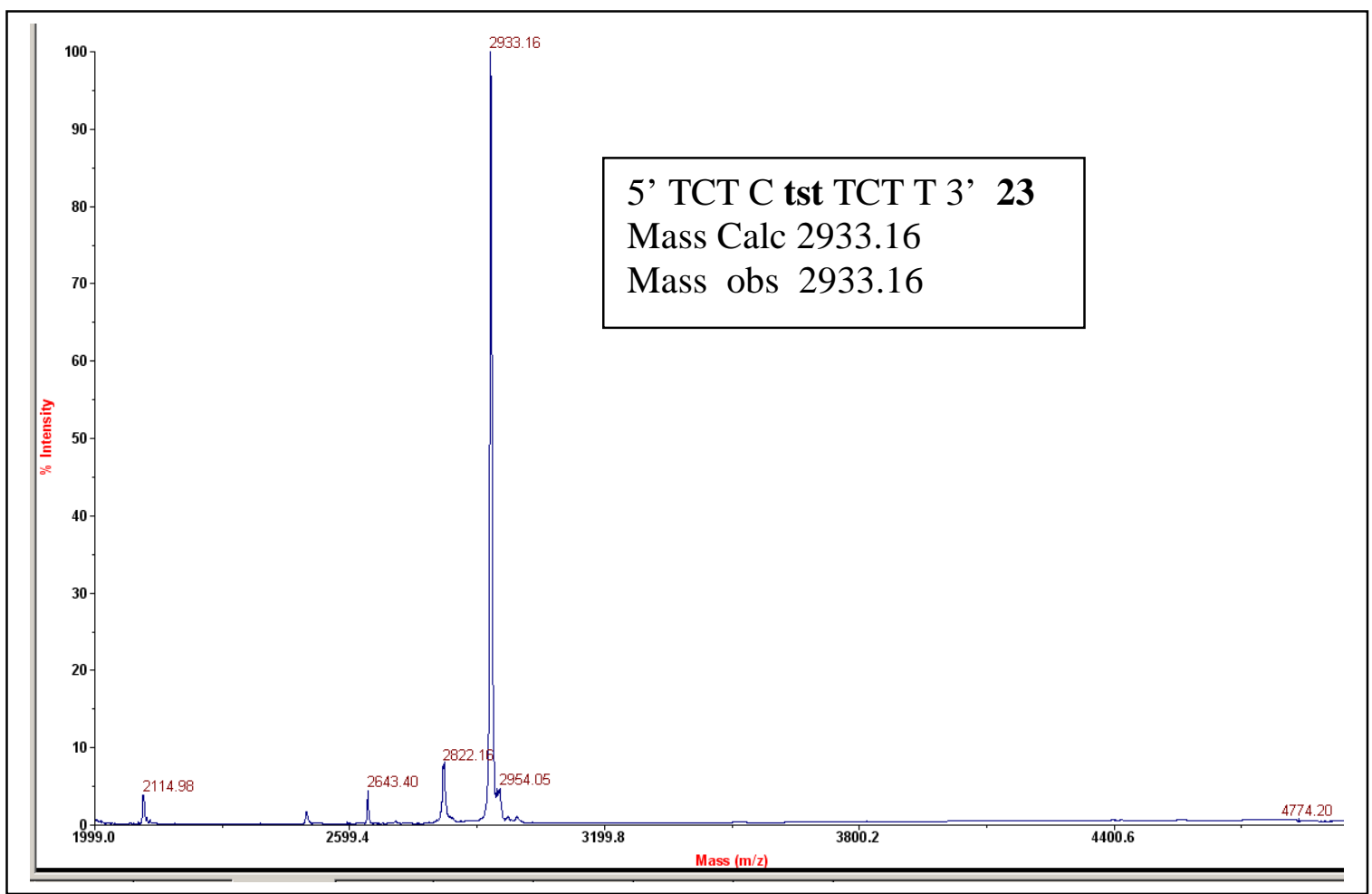

Figure S27: MALDI-TOF mass of 23 


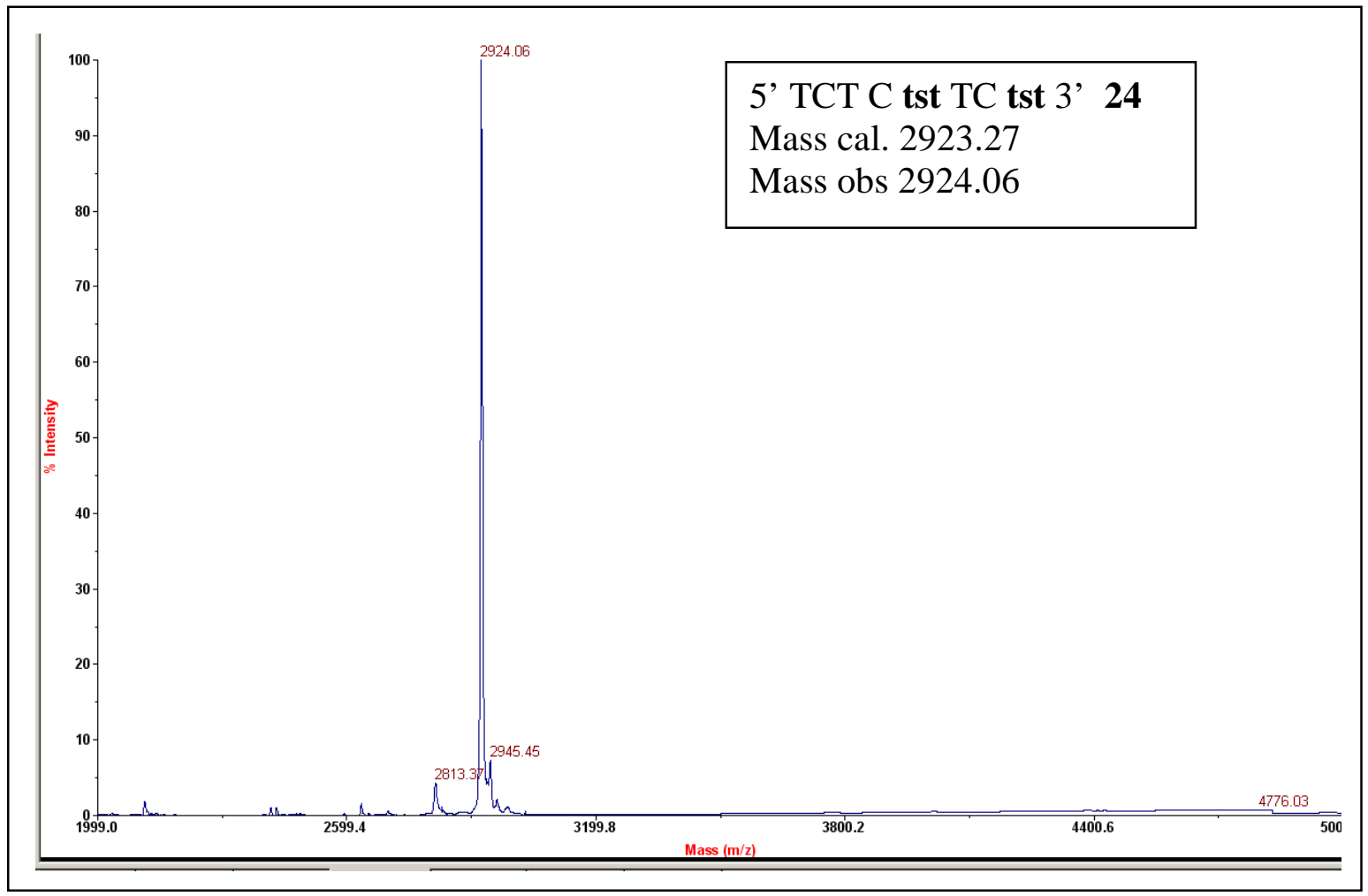

Figure S28: MALDI-TOF mass of 24

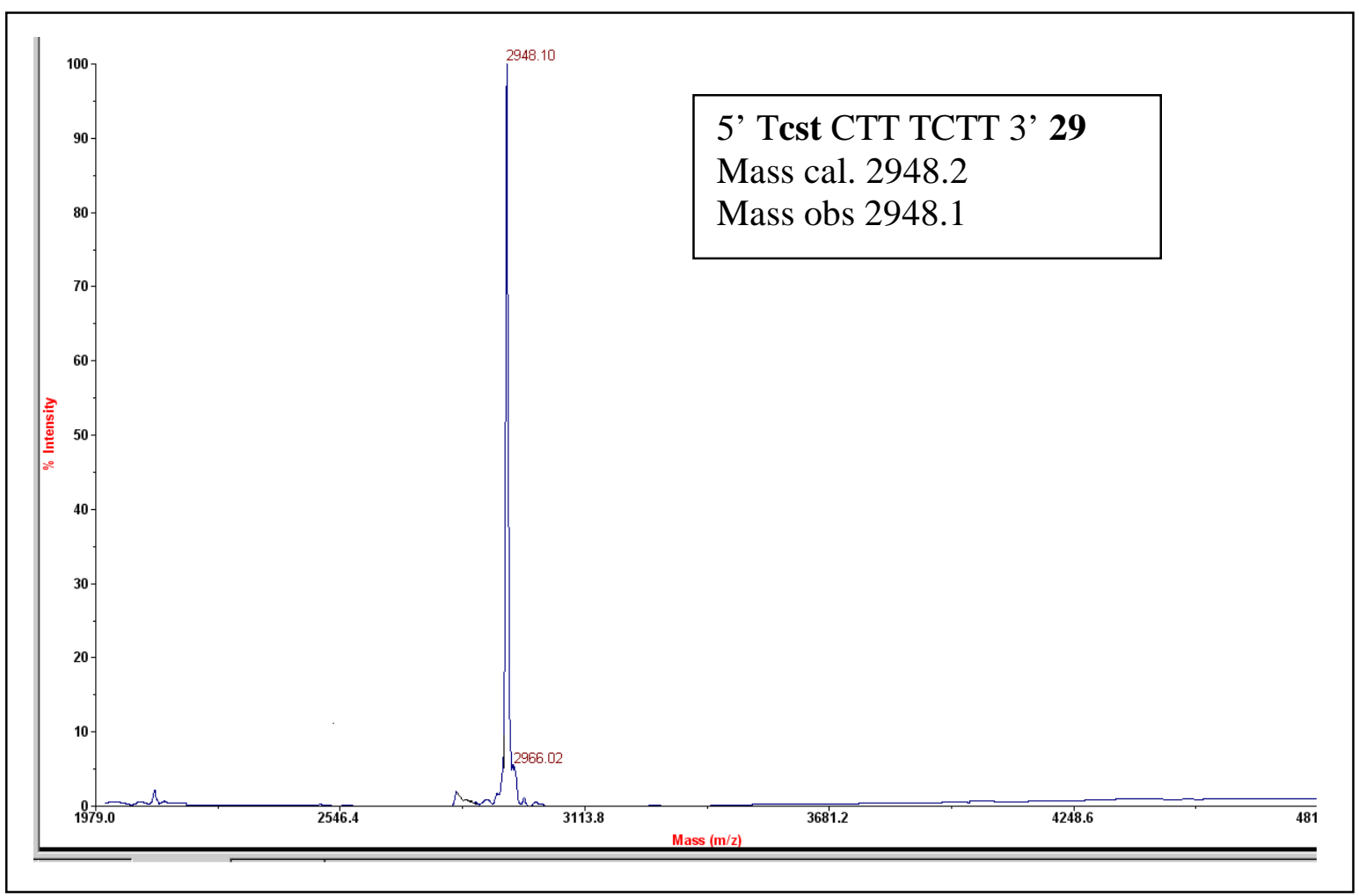

Figure S29: MALDI-TOF mass of 29 


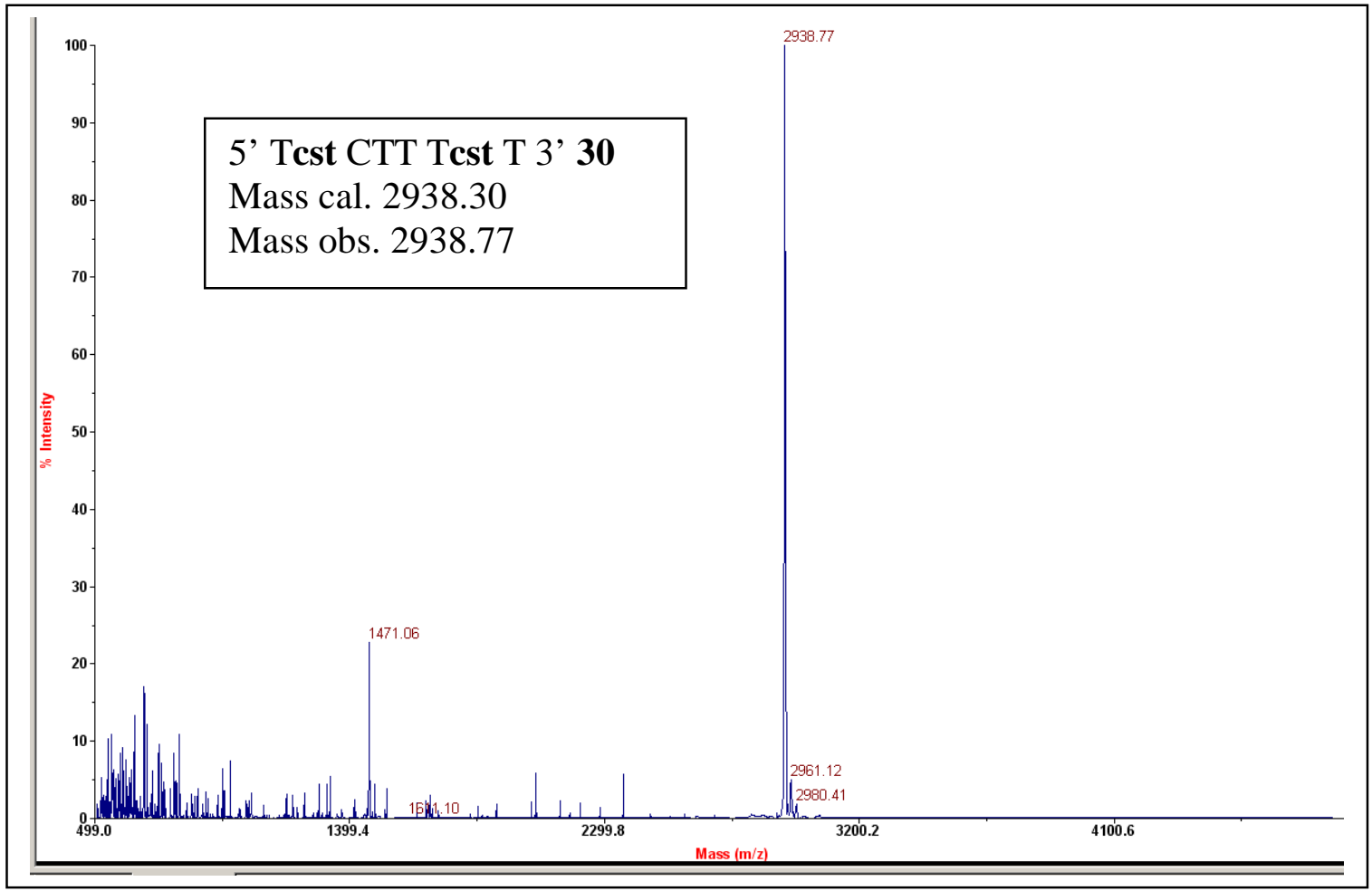

Figure S30: MALDI-TOF mass of $\mathbf{3 0}$

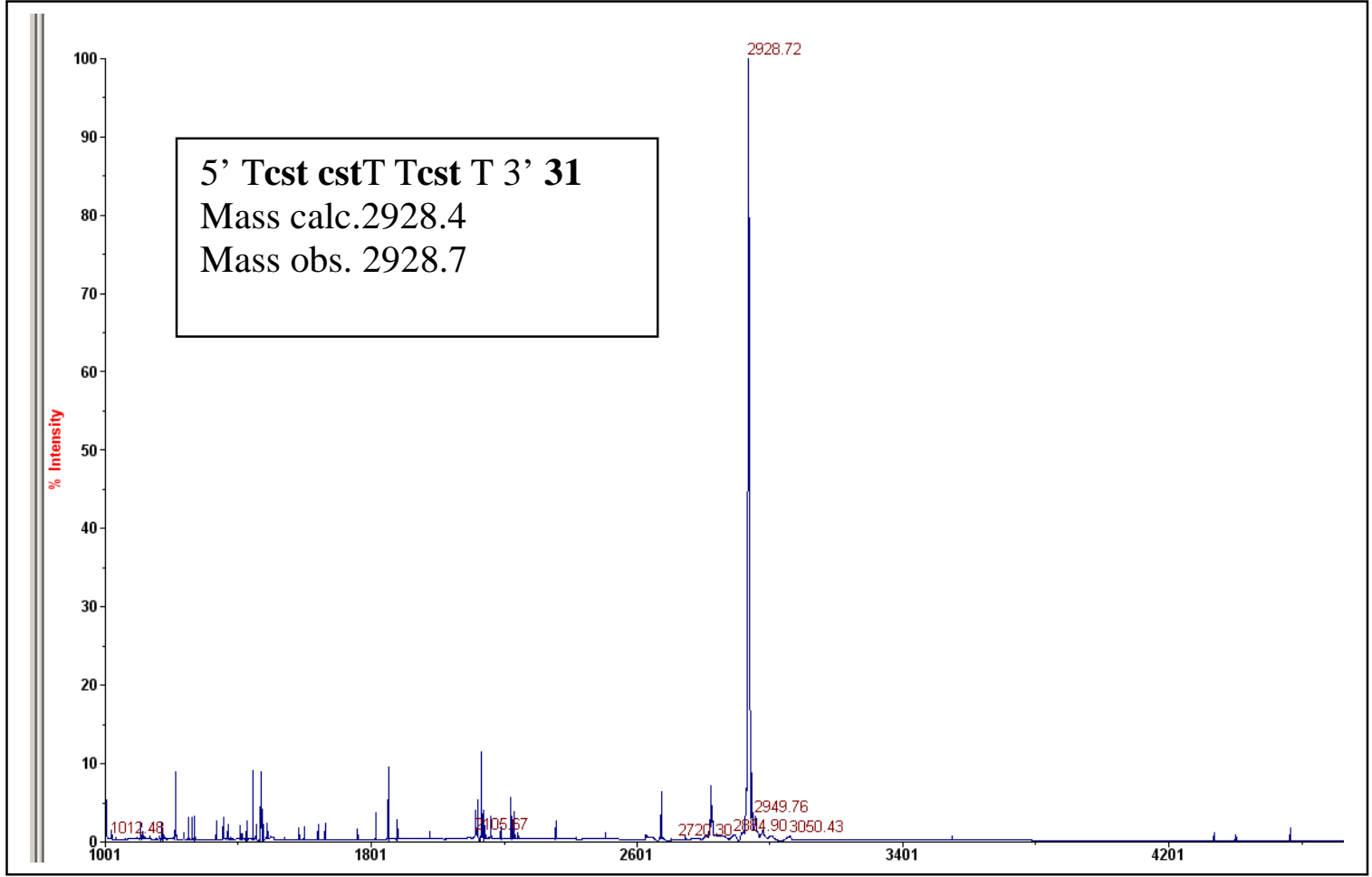

Figure S31: MALDI-TOF mass of 31 


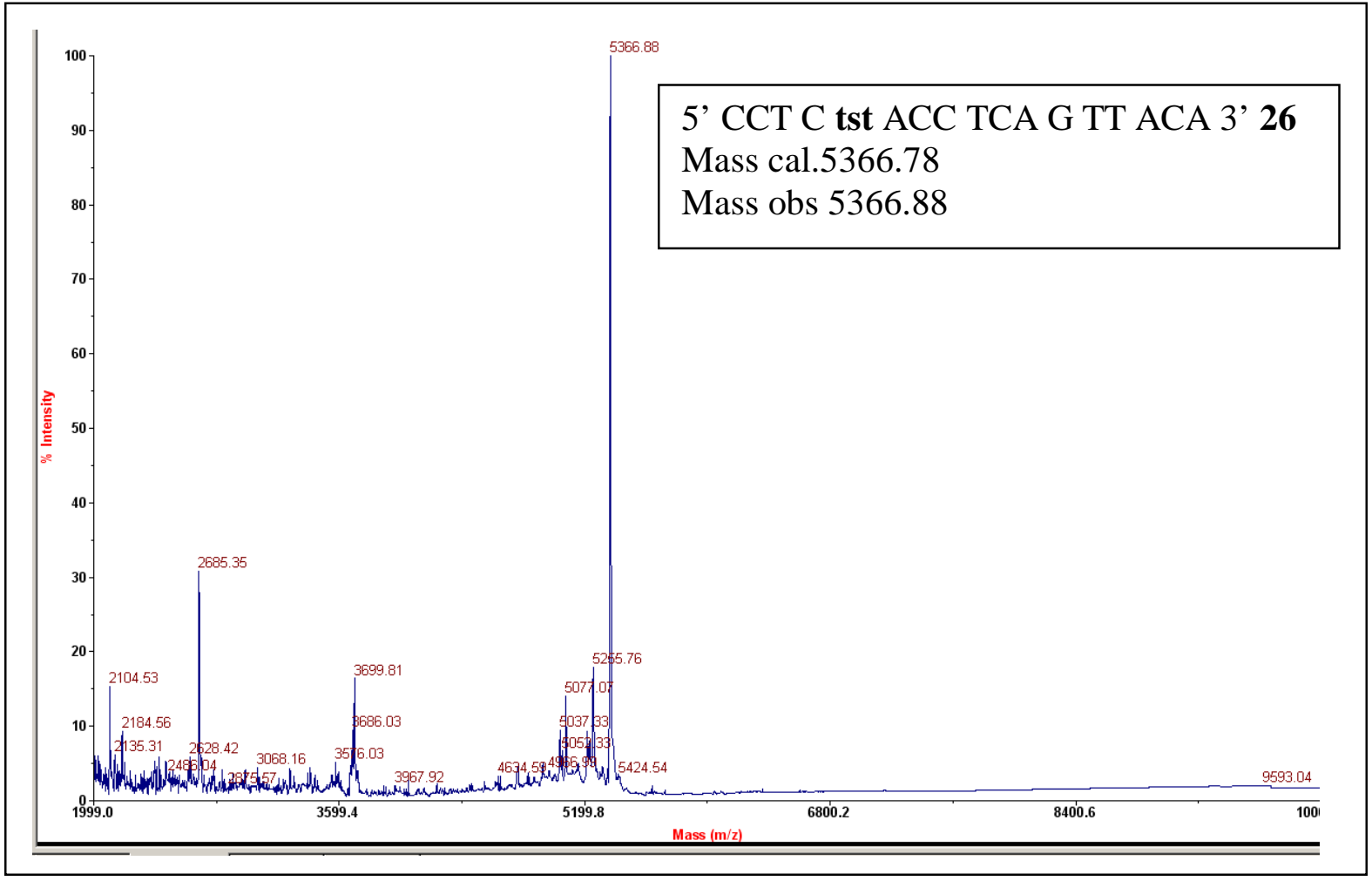

Figure S32: MALDI-TOF mass of 26

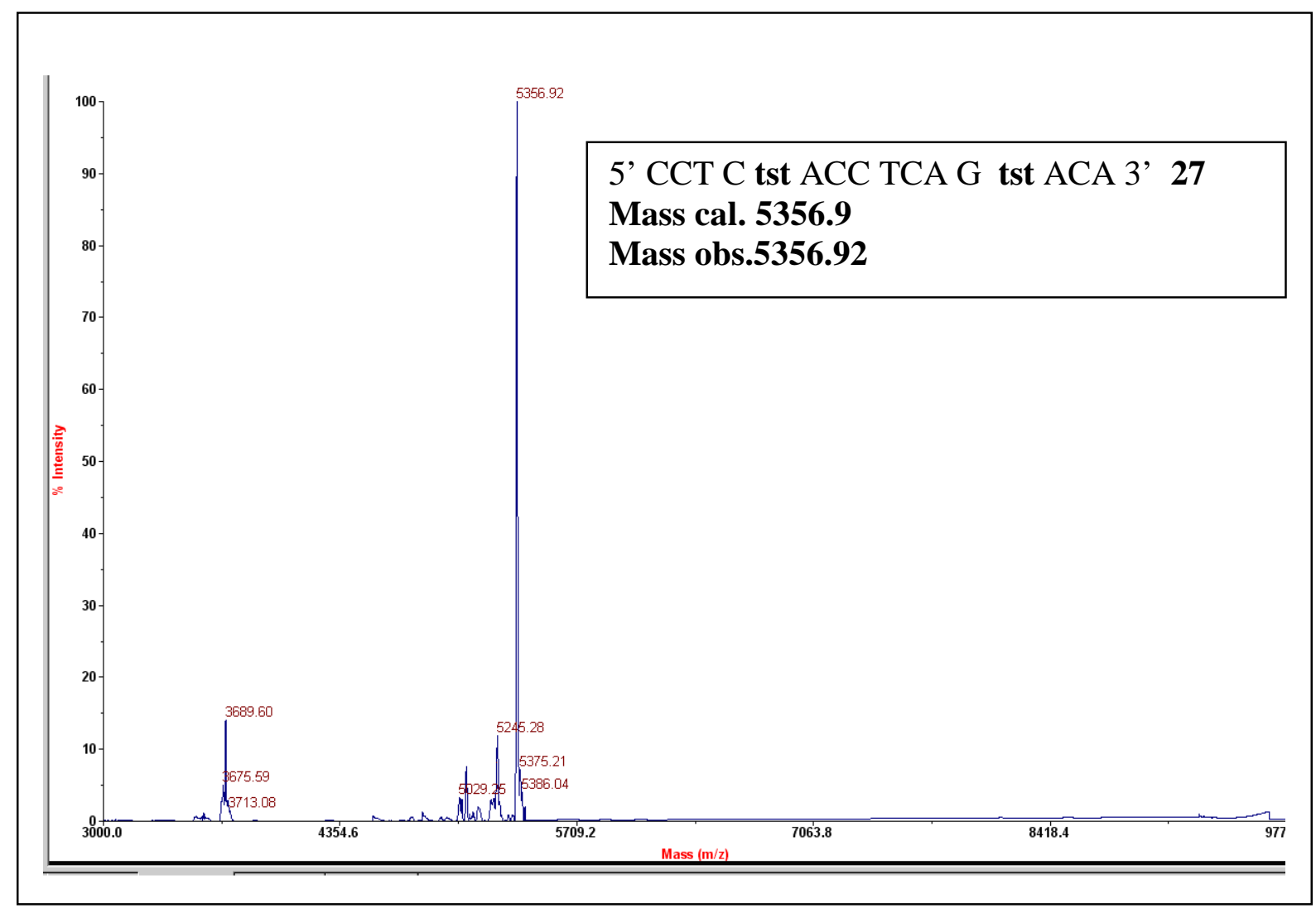

Figure S33: MALDI-TOF mass of 27 


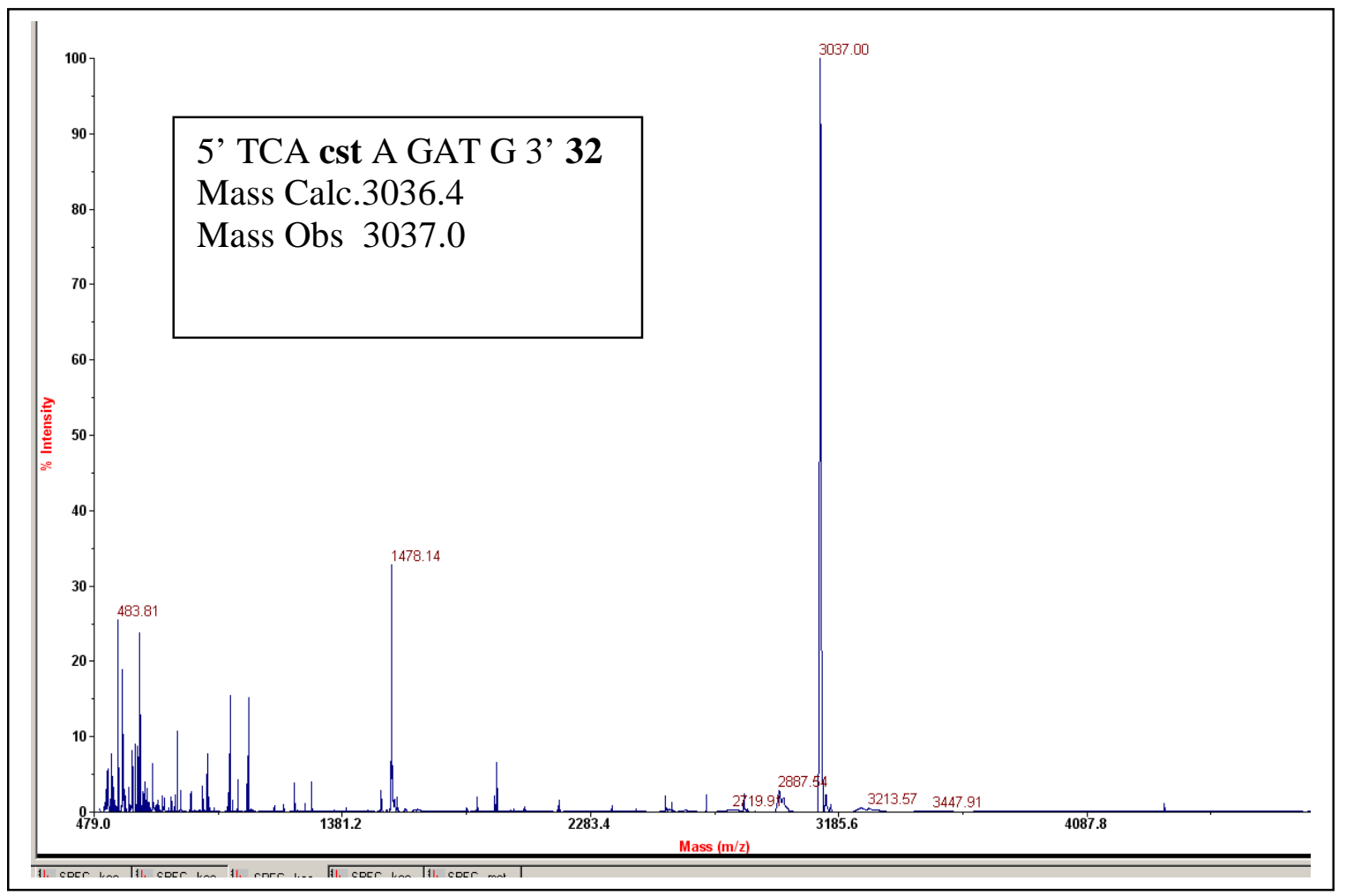

Figure S34: MALDI-TOF mass of 32 
UV-Tm measurements: The complementary DNA and RNA oligomers were synthesized on an Applied Biosystems 3900 DNA Synthesizer. The concentration was calculated on the basis of absorbance from the molar extinction coefficients of the corresponding nucleobases. The experiments were performed in 1-2 $\mu \mathrm{M}$ concentrations. The complexes were prepared in $10 \mathrm{mM}$ sodium phosphate buffer, $\mathrm{pH} 7.0$ containing $\mathrm{NaCl}(100 \mathrm{mM})$ and EDTA $(0.1 \mathrm{mM})$ and were annealed by keeping the samples at $90^{\circ} \mathrm{C}$ for 5 minutes followed by slow cooling to room temperature. Absorbance versus temperature profiles were obtained by monitoring at $260 \mathrm{~nm}$ with Perkin-Elmer Lambda 35 spectrophotometer scanning from 5 to $85^{\circ} \mathrm{C}$ at a ramp rate of $0.5^{\circ} \mathrm{C}$ per minute. The data were processed using Microcal Origin 6.1 and $T \mathrm{~m}$ values derived from the derivative curves. All values are an average of at least 3 experiments and accurate to within $\pm 0.5^{\circ} \mathrm{C}$.

Table S3 $T \mathrm{~m}\left({ }^{\circ} \mathrm{C}\right)$ values of ON: DNA / RNA duplex

\begin{tabular}{|c|c|c|c|c|}
\hline Entry & DNA Sequence & DNA34 & RNA35 & $\Delta T \mathrm{~m}_{(\mathrm{RNA}-\mathrm{DNA})}$ \\
\hline 1 & 5' CGTTTTTTTTGC 3' 33 & 40 & 32.0 & -8.0 \\
\hline 2 & 5' CG TTtstTTT TGC 3' 20 & 23.7 & 32.3 & 8.6 \\
\hline 3 & 5' CGTT tst TT tst GC 3' 21 & nd & 50.0 & - \\
\hline 4 & $5^{\prime} \mathrm{CG}$ tst tst tst tst GC 3' 22 & nd & 47.81 & - \\
\hline
\end{tabular}

DNA 34 5' GCAAAAAAAACG 3' RNA 35 r (5' GCAAAAAAAACG 3')
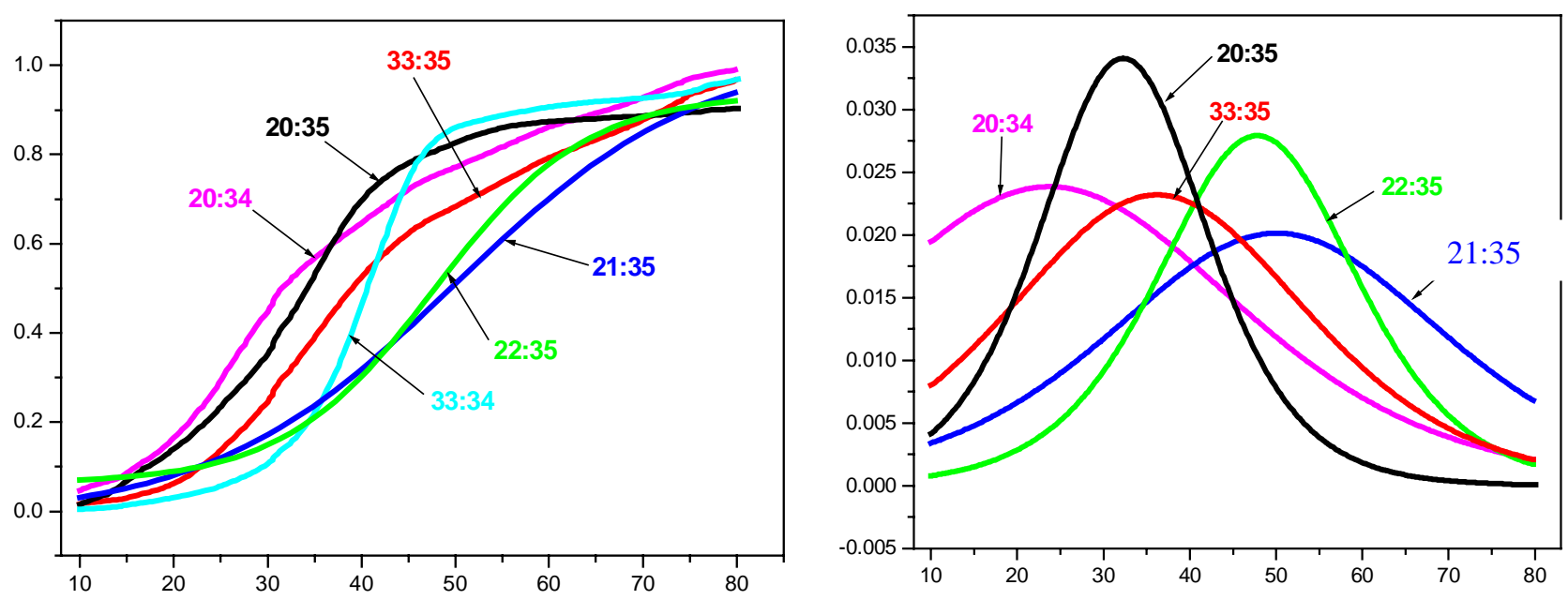

Figure S35: A. UV-melting Curves of 20, 21, 22 and 33 with cDNA (34) and cRNA (35) B. Corresponding first derivative Curves. 
Table S4: $T \mathrm{~m}\left({ }^{\circ} \mathrm{C}\right)$ values of ON:DNA/RNA duplex

\begin{tabular}{|l|ll|l|l|l|}
\hline Entry & Sequence & DNA 37 & RNA 38 & $\Delta T_{\text {(RNA-DNA) }}$ \\
\hline 1 & 5' CCT CTT ACC TCA GTT ACA 3' $^{\prime} \mathbf{3 6}$ & 54.6 & 54.7 & 0.1 \\
\hline 2 & 5' CCT C tst ACC TCA G TT ACA 3' $\mathbf{2 6}$ & 39.6 & 47.5 & 7.9 \\
\hline 3 & 5' CCT C tst ACC TCA G tst ACA 3' 27 & 43.5 & 52.8 & 9.3 \\
\hline
\end{tabular}

DNA 37 5' TGT AAC TGA GGT AAG AGG 3'

RNA 38 r (5' TGT AAC TGA GGT AAG AGG 3')
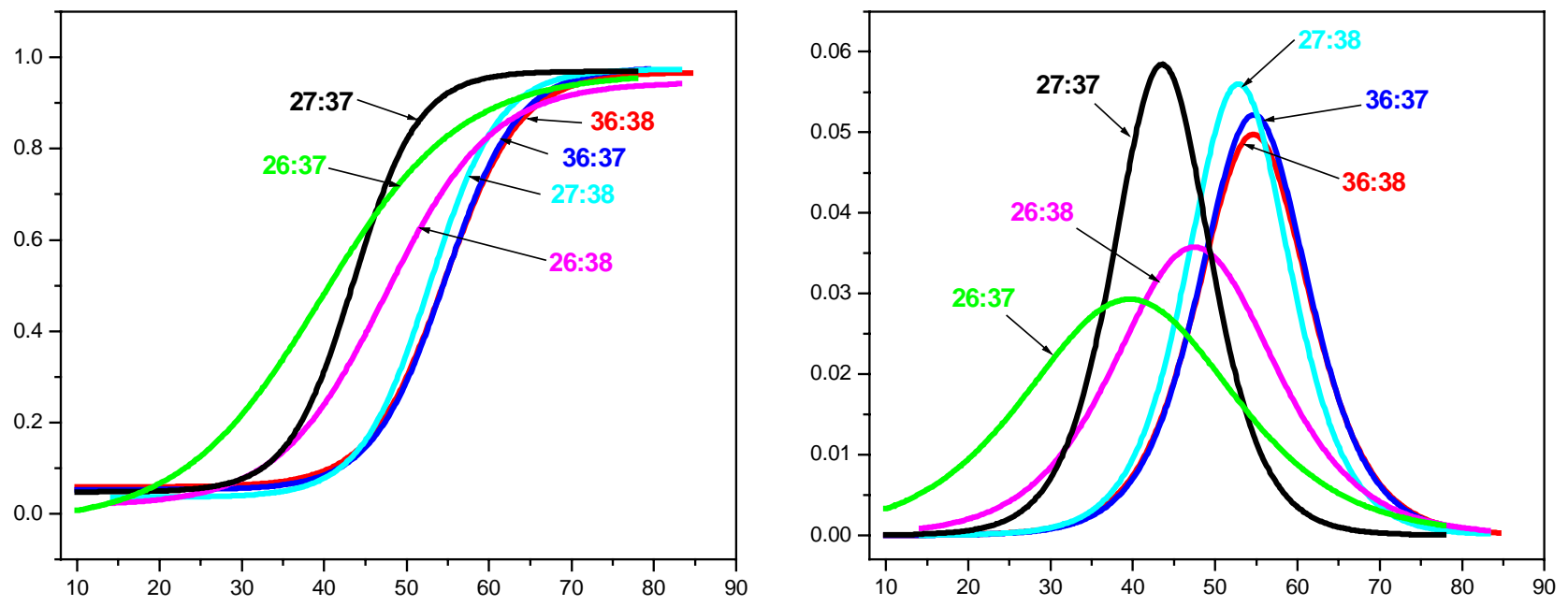

Figure S36: C. UV-melting Curves of 26, 27 and 36 with cDNA (37) and cRNA (38) D. Corresponding first derivative Curves.

Table S5: $\operatorname{Tm}\left({ }^{\circ} \mathrm{C}\right)$ values of ON:DNA /RNA duplex

\begin{tabular}{|c|c|c|c|c|}
\hline Entry & Sequence & DNA 40 & RNA 41 & $\begin{array}{l}\Delta T \mathrm{~m}_{\text {(RNA- }} \\
\text { DNA) }\end{array}$ \\
\hline 1 & 5' ТСТ СТТ ТСТ Т 3' 39 & 23.6 & 27.3 & 3.7 \\
\hline 2 & 5' TCT C tst TCT T 3' 23 & nd & 31 & - \\
\hline 3 & 5' TCT C tst TC tst 3' 24 & nd & 33.8 & - \\
\hline 4 & 5' Test CTT TCTT 3' 29 & 18.5 & 27.5 & 9 \\
\hline 5 & 5' Test CTT Test T 3' 30 & nd & 32.6 & - \\
\hline 6 & $5^{\prime}$ Test cstT Test T 3' 31 & nd & 39.7 & - \\
\hline
\end{tabular}

DNA 40 5’ AAG AAA GAG A3' RNA 41 r (5’ AAG AAA GAG A 3') 

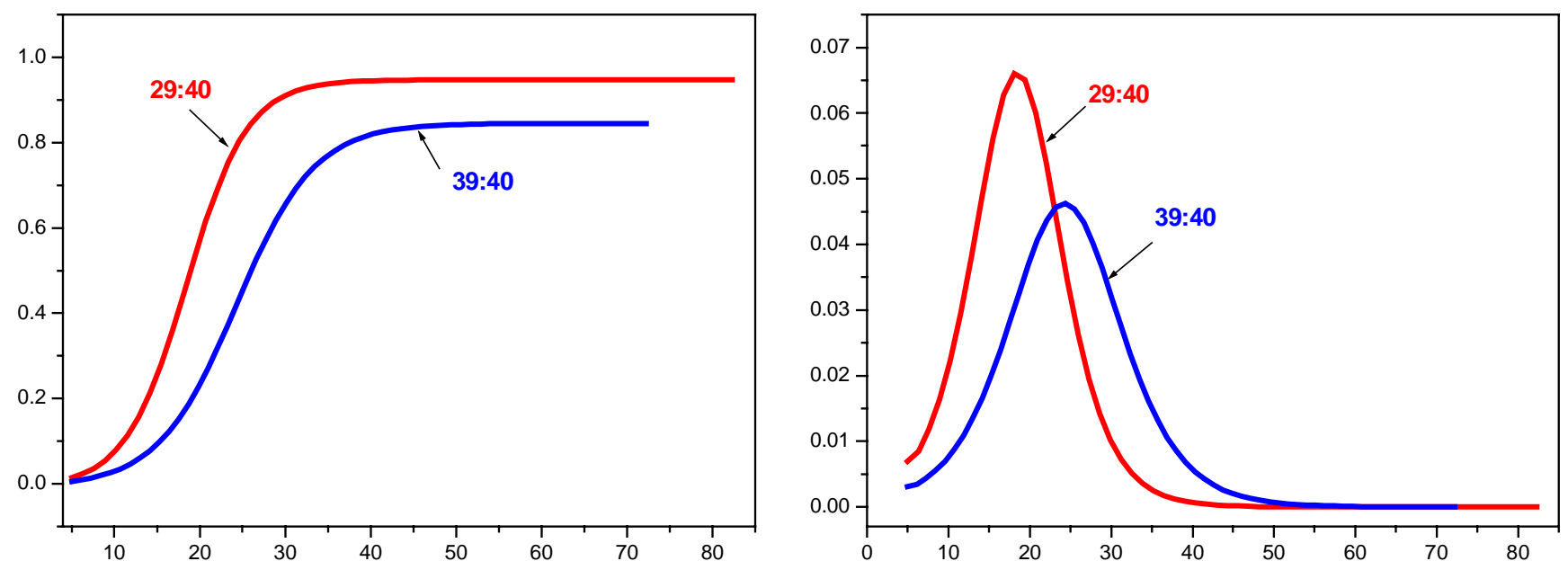

Figure S37: E. UV-melting Curves of 29 and 39 with cDNA (40) D. Corresponding first derivative Curves.
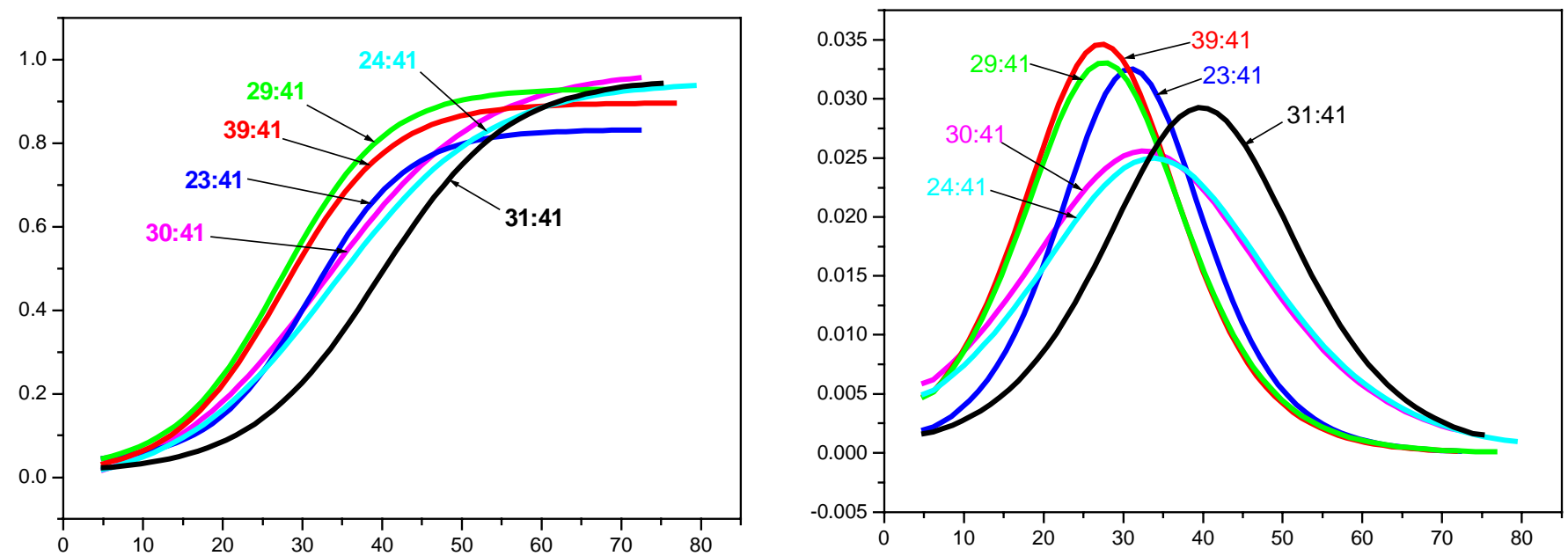

Figure S38: G. UV-melting Curves of 23, 24, 29, 30, 31 and 39 with cRNA (41) H. Corresponding first derivative Curves. 
Table S6: $T \mathrm{~m}\left({ }^{\circ} \mathrm{C}\right)$ values of ON:DNA /RNA duplex

\begin{tabular}{|l|l|l|l|l|}
\hline Entry & Sequence & DNA 43 & RNA 44 & $\Delta T_{\text {(RNA-DNA) }}$ \\
\hline 1 & $5^{\prime}$ TCA CTA GAT G 3' 42 & 24.3 & 24.7 & 0.4 \\
\hline 2 & $5^{\prime}$ 'TCA cst A GAT G 3' 32 & 16.3 & 29.6 & 13.3 \\
\hline
\end{tabular}

\section{DNA 43 5'CAT CTA GAG A3' RNA 44 r (5'CAT CTA GAG A3')}
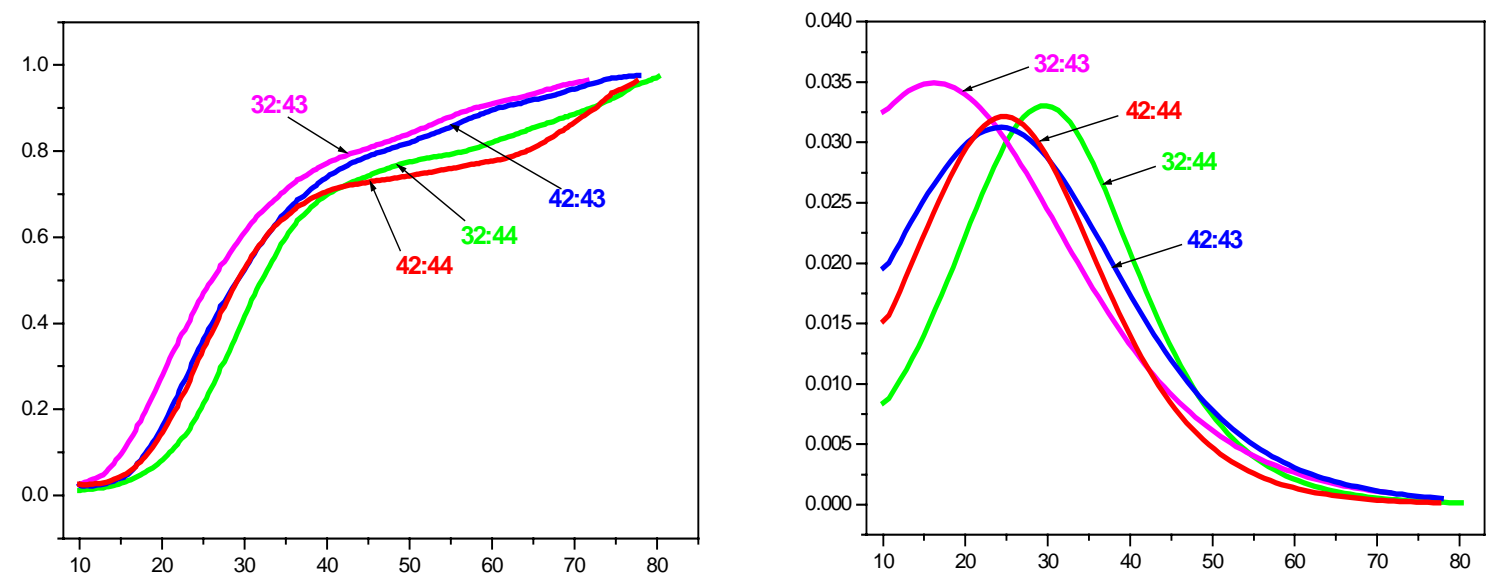

Figure S39: I. UV-melting Curves of 32 and 42 with cDNA (43) and cRNA (44) J. Corresponding first derivative Curves. 

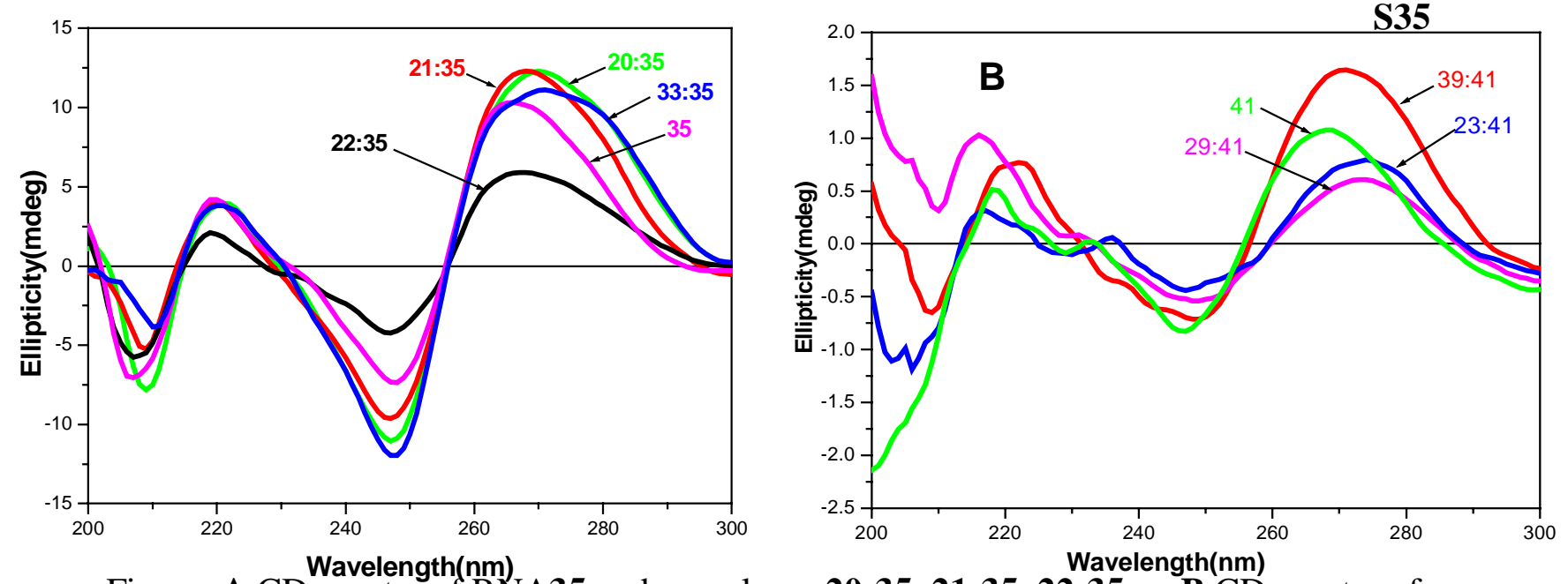

Figure: A.CD spectra of RNA35 and complexes 20:35, 21:35, 22:35 B.CD spectra of RNA 41 and complexes 39:41, 23:41, 29:41.
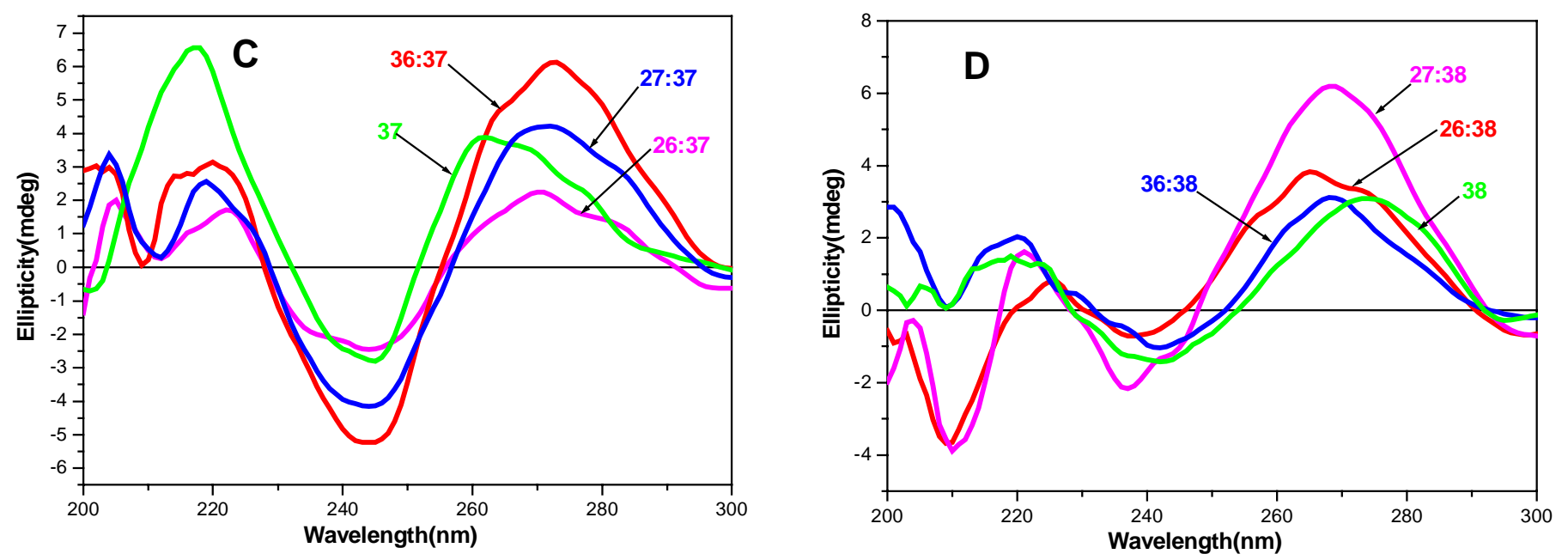

Figure: C. CD spectra of DNA37 and complexes 36:37, 26:37 and 27:37 D. CD spectra of RNA38 and complexes 36:38, 26:38 and 27:38

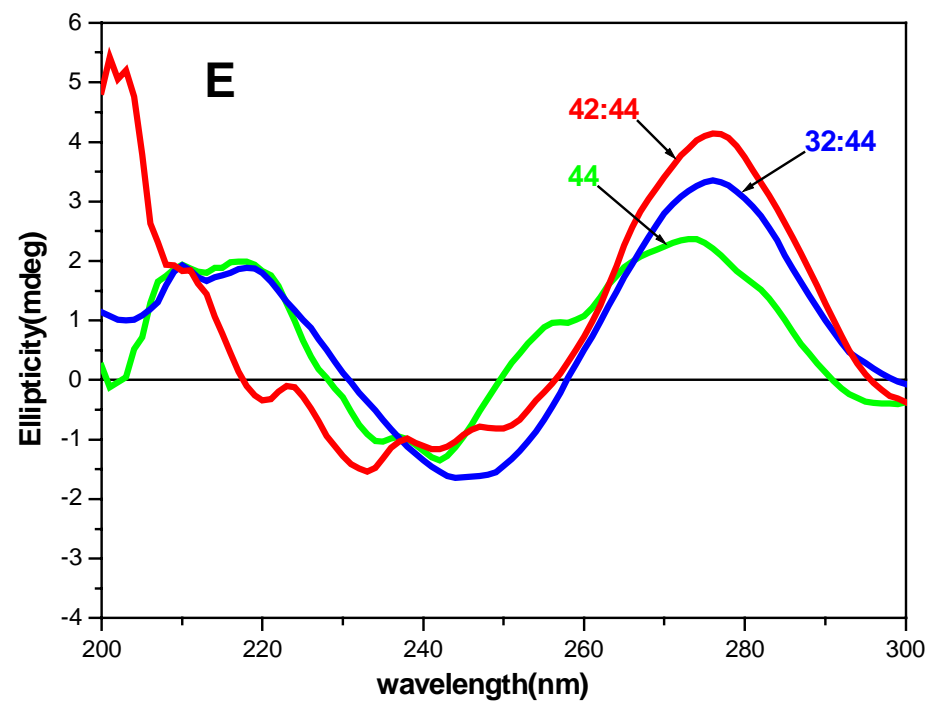

Figure: E. CD spectra of RNA 44 and complexes 42:44, 32:44. 
S36
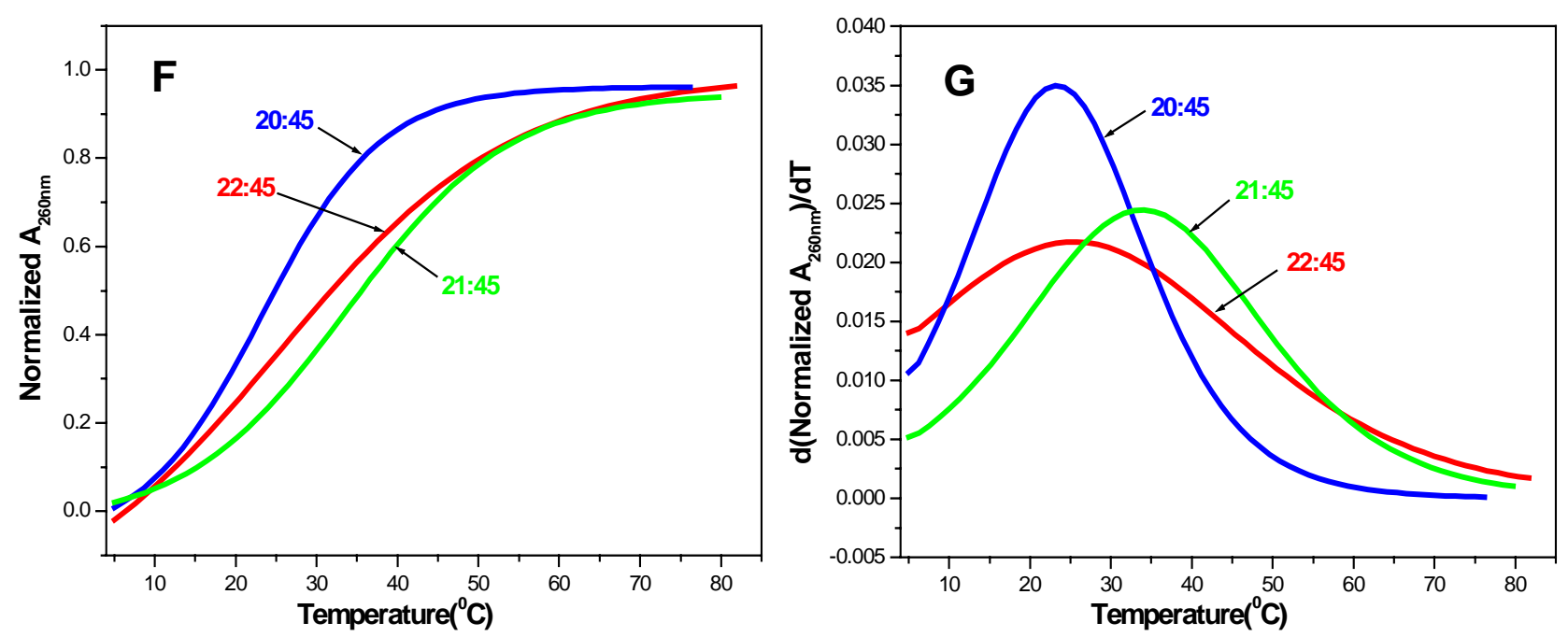

Figure: F. Mismatch melting curves of ONs 20, $21 \& 22$ with mismatch RNA 45 r (5' GCAAAUAAAACG 3')

G.Corresponding derivative curves.
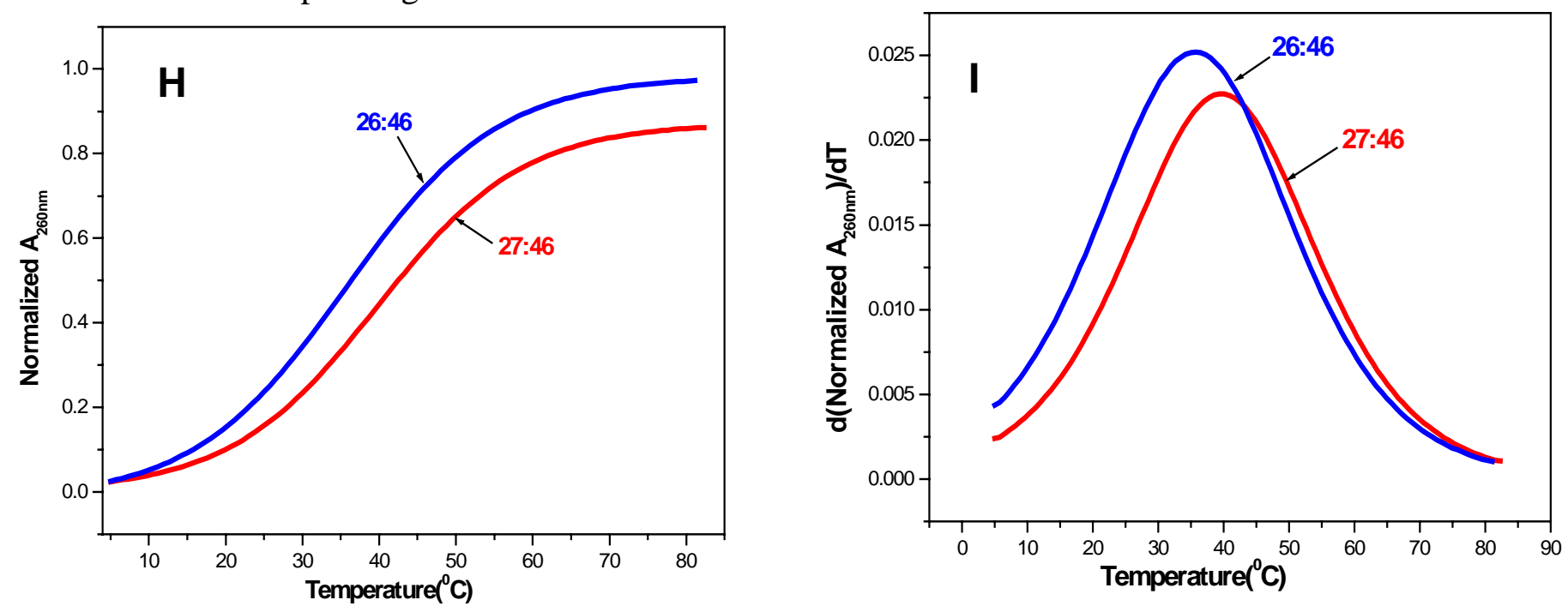

Figure: H. Mismatch melting curves of ONs 26 \& 27 with mismatch RNA 46 r (5' UGU AAC UGA CGU AAG AGG 3') I.Corresponding derivative curves 
Table S7: Mismatch UV-melting studies of modified ONs:RNA

\begin{tabular}{|c|c|c|c|}
\hline $\begin{array}{l}\text { En } \\
\text { try }\end{array}$ & ON Sequences & $\begin{array}{l}\text { ON: cRNA } \\
T_{\mathrm{m}}{ }^{\circ} \mathrm{C}\end{array}$ & $\begin{array}{l}\text { ON:Mismatch } \\
\text { RNA } T_{\mathrm{m}}{ }^{\circ} \mathrm{C}\end{array}$ \\
\hline 1 & 5' CG TTtstTTT TGC 20 & $\begin{array}{l}\mathbf{2 0 : 3 5} \\
32.3\end{array}$ & $\begin{array}{l}\mathbf{2 0 : 4 5} \\
23.3(-9)\end{array}$ \\
\hline 2 & 5' CGTT tst TT tst GC 21 & $\begin{array}{l}\mathbf{2 1 : 3 5} \\
50.0\end{array}$ & $\begin{array}{l}\mathbf{2 1 : 4 5} \\
33.9(-16.1)\end{array}$ \\
\hline 3 & 5' CG tst tst tst tst GC 22 & $\begin{array}{l}\mathbf{2 2 : 3 5} \\
47.8\end{array}$ & $\begin{array}{l}\mathbf{2 2 : 4 5} \\
25.4(-22.4)\end{array}$ \\
\hline 4 & 5' CCT C tst ACC TCA G TT ACA 26 & $\begin{array}{l}\mathbf{2 6 : 3 8} \\
47.5\end{array}$ & $\begin{array}{l}\mathbf{2 6 : 4 6} \\
35.7(-11.8)\end{array}$ \\
\hline 5 & 5' CCT C tst ACC TCA G tst ACA 27 & $\begin{array}{l}\mathbf{2 7 : 3 8} \\
52.8\end{array}$ & $\begin{array}{l}\mathbf{2 7}: 46 \\
39.7(-13.1)\end{array}$ \\
\hline
\end{tabular}

RNA 35 r (5' GCAAAAAAAACG 3'), RNA 45 r (5' GCAAAUAAAACG 3')

RNA 38 r (5' UGU AAC UGA GGU AAG AGG 3')

RNA 46 r (5' UGU AAC UGA CGU AAG AGG 3')

Values in the parenthesis indicate the decreased melting temperature when hybridized with mismatch RNA 